\title{
Research advances and prospects of legume lectins
}

\author{
Rajan Katoch*(i) and Ankur Tripathi \\ Biochemistry Laboratory, Department of Genetics and Plant Breeding, CSKHPKV, \\ Palampur 176 062, India \\ *Corresponding author (Email, rajankatoch@yahoo.com)
}

MS received 30 October 2020; accepted 28 September 2021

\begin{abstract}
Lectins are widely distributed proteins having ability of binding selectively and reversibly with carbohydrates moieties and glycoconjugates. Although lectins have been reported from different biological sources, the legume lectins are the best-characterized family of plant lectins. Legume lectins are a large family of homologous proteins with considerable similarity in amino acid sequence and their tertiary structures. Despite having strong sequence conservation, these lectins show remarkable variability in carbohydrate specificity and quaternary structures. The ability of legume lectins in recognizing glycans and glycoconjugates on cells and other intracellular structures make them a valuable research tool in glycomic research. Due to variability in binding with glycans, glycoconjugates and multiple biological functions, legume lectins are the subject of intense research for their diverse application in different fields such as glycobiology, biomedical research and crop improvement. The present review specially focuses on structural and functional characteristics of legume lectins along with their potential areas of application.
\end{abstract}

Keywords. Legume lectins; carbohydrate specificity; biological functions; antiviral function; biomedical research

\begin{abstract}
Abbreviations: BFL, Bauhinia forficata Lectin; CRD, Carbohydrate recognition domains; ConA, Concanavalin A; ConBr, Canavalia brasiliensis Lectin; Cramoll, Cratylia mollis Lectin; DBL, Dolichos biflorus Lectin; DLL, Dolichos lablab Lectin; DVL, Dioclea virgata Lectin; ECL, Erythrina cristagalli Lectin; EcorL, Erythrina corallodendron Lectin; FRIL, Flt3 receptor-interacting lectin; Fuc, Fucose; Gal, Galactose; GalNAc, N-acetyl-D-galactosamine; Glc, Glucose; GlcNAc, N-Acetyl-D-glucosamine; GSL, Griffonia simplicifolia Lectin; LCA, Lens culinaris Agglutinin; LTA, Lotus tetragonolobus Lectin; MAL, Maackia amurensis Lectin; Man, Mannose; PHA, Phytohaemagglutinin agglutinin; PNA, Peanut agglutinin; PSA, Pisum sativum Agglutinin; RPbAI, Robinia pseudoacacia Lectin; SBA, Soyabean agglutinin; SPL, Spatholobus parviflorus Lectin; TCLL, Tamarind chitinase like lectin; TLR, Toll like receptor; TxLC-I, Tulipa hybrid lectin I; UEA, Ulex europeus Agglutinin; VFL, Vicia faba Lectin; VML, Vatairea macrocarpa Lectin; WFA, Wisteria floribunda Agglutinin; WGA, Wheat germ agglutinin.
\end{abstract}

\section{Introduction}

Lectins recognize and bind carbohydrate moieties and glycoconjugates selectively and reversibly without changing the structure of glycan. The carbohydrate specificity of lectins distinguishes these proteins from other proteins. Lectins are ubiquitous present in nature and their presence has been detected from different biological sources of which plant lectins are thoroughly investigated (Van Damme 2014; Cavada et al. 2019).
Plant lectins constitute a heterogeneous group owing to their biochemical and physicochemical properties, evolutionary relationships, molecular structure, and carbohydrate specificity. They have been known to play important cellular and biological functions for which lectins have always been a subject of intense research (Ingale and Hivrale 2013). Though many lectins have been investigated from different plants, legume lectins are the extensively investigated plant lectin family (Cavada et al. 2020). These lectins have 
been reported in higher amounts from seeds but they also present in lesser amounts in vegetative parts of the plants. Legume lectins are one of the important families of homologous proteins and share high sequence and structural similarity (Grandhi et al. 2015). Relationships between the sequences of legume lectins within the same family suggest that these lectins most probably arose from divergent evolution from a single common ancestor. Till date, several lectins from different legumes have been investigated in detail to study their structural and functional characteristics. The existence of carbohydrate-binding domain (CRD; Procópio et al. 2017a) is an important factor for their biological properties and their future biomedical and biotechnological applications. Legume lectins show strong relatedness in primary structure and tertiary structure. Despite this, they show variation in carbohydrate specificities and quaternary structure (Grandhi et al. 2015; Lagarda-Diaz et al. 2017). The variability in carbohydrate-binding specificities of legume lectins makes them a potential tool in glycobiology (Coelho et al. 2017). This review provides a comprehensive and up to date information on structural and biological properties, technological interventions and areas of potential applications of legume lectins.

\section{Lectin classes and distribution}

More than a century ago, Stillmark (1888) gave the first description of lectins while investigating the effect of castor bean extract (Ricinus communis) on red blood cells. He gave the name ricin to the proteins causing agglutination of red blood cells. Later, another lectin named as 'abrin' was isolated from Abrus precatorius seeds. Boyd and Shapleigh introduced the term lectin in the year 1954. The word lectin is taken up from a Latin verb 'legere' which has the meaning of 'to pick up or to choose' (Boyd and Shapleigh 1954). Since the first insight of lectins, numerous lectins from different plants have been isolated and investigated. ConA was the first lectin, isolated in its pure form by Summner and Howell (1936) from Jack bean seeds (Canavalia ensiformis). ConA was also the first lectin whose primary and 3D structures were resolved (Edelman et al. 1972; Hardman and Ainsworth 1972). Lima bean lectin was the first plant lectin that had shown blood group specificity (Boyd and Reguera 1949).

Although, lectins have been reported from varied sources, plant lectins constitute a heterogeneous group of glycoproteins. These proteins show heterogeneity in displaying diverse biological functions owing to their specific carbohydrate-binding property (Goldstein and Hayes 1978). Though the term 'lectin' initially introduced describing the property of some proteins having selective carbohydrate binding and the ability to agglutinate erythrocytes (Peumans and Van Damme 1995), studies have added more information on the earlier definition of lectins. Interestingly some plant enzymes have fused carbohydrate binding and catalytic domain and reveal similar properties as lectins have (Collinge et al. 1993). A few type II RIP's also known as polynucleotide: adenine glycosidase consists of two chains i.e., toxic chain (A) and carbohydrate-binding chain (B) (Barbieri et al. 1993). Some proteins have also been identified with only one carbohydrate-binding site and unable to precipitate glycoconjugates (Van Damme et al. 1994). Additionally, other proteins have also been related to lectins in plants but devoid of any carbohydrate-binding property. Based on these observations, lectins are defined as 'Any storage proteins possessing at least one non-catalytic domain which binds reversibly to specific mono or oligosaccharides' (Peumans and Van Damme 1995).

Lectins are ubiquitously distributed glycoproteins characterized for their carbohydrate-binding properties. Lectins have been identified from animals, plants, and microorganisms (Sharon and Lis 2001; Chandra et al. 2006). Numerous lectins have been isolated from plants and in-depth investigated for biochemical and functional characterization. Lectins are distributed in different plant tissues and their amount depends on developmental stage and pathological state. Their highest amount is reported from seeds; therefore they are mainly characterized as storage proteins. In seeds, they mainly accumulate either in vacuoles and may comprise $1 \%$ to up to $10 \%$ of total seed proteins (Laija et al. 2010). However, sometimes they constitute about $50 \%$ of the total storage proteins (Van Damme et al. 2008). In seeds, lectins are synthesized as preprecursor molecule and sequestered in protein bodies during seed development and broken down during seed germination for providing essential amino acids. Apart from seeds, lectins have also been identified from vegetative tissues in low concentration. Additionally, plants also express minute amounts of lectins in response to abiotic and biotic stresses. In absence of stress, inducible lectins are not synthesized at detectable levels. The synthesis of these lectins is regulated by the cross talk of different plant hormones (Babosha 2008). The most investigated plant lectins belong to the family Leguminosae and most of them have been purified from mature seeds. Legume lectins have broad specificity in 
binding with carbohydrate moieties and glycoconjugates. Among various legume lectins, PHA and ConA are the most investigated legume lectins (Loris et al. 1998).

Plant lectins have been classified based on their carbohydrate-binding specificity, molecular structure, abundance, and subcellular localization into different groups. Merolectins have a single carbohydrate-binding domain and don't have agglutination activity. Hololectins have two or more identical carbohydratebinding domains, which bind either same or structurally similar sugars. Hololectins are di- or multivalent in structure and have agglutination activity. Chimerolectins are fusion proteins for having carbohydratebinding domain fused with other catalytically active domain. Superlectins are a special type of chimerolectins containing two or more fused carbohydratebinding domains (Van Damme et al. 2011).

Based on their carbohydrate-binding specificity lectins have been classified as (i) Mannose/glucose binding; (ii) Galactose $/ N$-acetyl-D-galactosamine binding; (iii) $\mathrm{N}$-acetyl-D-glucosamine binding; (iv) L-Fucose binding lectin; (v) Sialic acid binding (Goldstein and Poretz 1986; Van Damme et al. 1998). However, this classification doesn't give the whole picture of carbohydrate specificity of lectins as some lectins recognize and bind with complex glycan structures. Moreover, some monosaccharides-specific lectins have also been identified with specificity to bind with oligosaccharides. Besides binding with carbohydrates, plant lectins are also able to bind with non-carbohydrate ligands such as 8-anilinonaphthalene-1-sulfonate (ANS) (Maliarik and Goldstein 1988), porphyrins (Pandey et al. 2009), and adenine (Shetty et al. 2013). Binding with non-carbohydrate molecules contributes to the diverse biological functions of plant lectins.

Plant lectins classification based on the ability to recognize and bind specific sugars does not give any information on evolutionary relationships. Based on comprehensive genome/ transcriptome analysis, plant lectins have been classified into 12 distinct families which are Agaricus bisporus agglutinin, Amaranthin, Chitinase-related lectins, Cyanovirin, Euonymus europaeus agglutinin, Galanthus nivalis lectin, Hevein, Jacalins, Legume lectins, LysM domain lectins, Nicotiana tabacum agglutinin (Nictaba) and Ricin B (Macedo et al. 2015) and each family is named after the highly investigated lectin.

Plant lectins have also been classified based on their expression pattern and subcellular localization. One group is classical lectins which are present in seeds and synthesizes constitutively from their inactive precursors with a signal sequence on RER and become active only after post-translational processing. After their biosynthesis, they are either stored in the vacuole or sorted to various extracellular compartments. These lectins have been reported to play crucial roles in plant developmental processes (De Hoff et al. 2009; Lannoo and Van Damme 2010; Nonomura et al. 2020) as well as in plant defense (Vandenborre et al. 2011; De Schutter and Van Damme 2015; Van Holle and Van Damme 2018). Another group includes inducible lectins, which are synthesized without signal peptide on free ribosomes and accumulate in the nucleus and cytoplasm (Van Holle et al. 2017; Lambin et al. 2020). Inducible lectins are present in lower amounts in normal conditions but their synthesis is induced after exposure to biotic and abiotic stress (Lannoo and Van Damme 2010; Vandenborre et al. 2011; Van Holle and Van Damme 2018).

Lectins are an important component of plant's innate immune system. Lectins recognize PAMP's (Pathogenassociated molecular patterns) and DAMP's (Damageassociated molecular patterns). PAMP's are pathogenderived elicitors [(Bacterial and fungal exopolysaccharides, peptidoglycan lipopolysaccharides and fungal cell wall fragments ( $\beta$-glucans, chitin, and chitosan)] whereas DAMP's are host-derived elicitors [cell wall fragments, short and long oligogalacturonides (degradation products of pectin), arabinogalactan proteins and small carbohydrate molecules (sucrose, trehalose raffinose, and glucose)] (Van Holle and Van Damme 2018). At the cell surface, lectin domains (LecPs, LecRLKs, and LecRLPs), constitute a crucial component of the plant's innate immune system (Bellande et al. 2017). After binding with PAMP's and DAMP's with lectin domains, a downstream signaling cascade is triggered which includes $\mathrm{Ca}^{2+}$ influx, ROS production, activation of MAP kinase pathway (Mitogen-Activated Protein Kinase Pathway) modulation of hormone biosynthesis and modulation of expression of defenserelated genes, and synthesis of defense molecules (Lanoo and Van Damme 2014; De Schutter and Van Damme 2015).

Nucleocytoplasmic lectins interact with various intracellular effectors and play a crucial role in plant defense via activating effector-triggered immunity. Some nucleocytoplasmic lectins alter transcriptional programming by chromatin remodeling during plant defense (Van Holle and Van Damme 2018). Recently, Sahid et al. (2020) reported that Osr40c1, a nucleocytoplasmic lectin from rice also interacts with OsSAM2 protein (S-adenosine methyltransferase 
enzyme) and induces polyamine biosynthesis to impart drought tolerance.

Despite playing a crucial role in plant defense, a few nucleocytoplasmic plant lectins have been investigated in detail (Van Holle and Van Damme 2018). Therefore, comprehensive efforts are required to generate more information on their endogenous ligands and their contribution to intracellular signaling during plant defense and development. The information available in the reviews (Van Damme et al. 2004; Lannoo and Van Damme 2010; Tsaneva and Van Damme 2020) will be helpful in conducting future research on nucleocytoplasmic plant lectins. The model showing lectin mediated signalling in plant defense is presented as figure 1.

\section{Biological implications of legume lectins}

Lectins recognize diverse sugar structures and have been shown to possess important biological activities due to which lectins are the focus of intense research.

\subsection{Agglutination}

Hemagglutination assay distinguishes lectin from the mixture of proteins thereby is the easiest method to detect lectins in biological sources. In agglutination reaction, lectin binds with erythrocytes and forms multiple cross-bridges between them. Agglutination inhibition with sugars confirms the detection of lectin indicated by agglutination assay (Moreira et al. 1991). The difference between the binding of lectins and other carbohydrate-binding proteins is that they will never change their carbohydrate-binding properties. Since lectins can easily bind with foreign glycans they are considered an important tool in glycobiology.

Antimicrobial lectins interact with the glycocomponents present on the cell surface of microorganisms, thereby interferes with their growth, multiplication, and spread. The antimicrobial actions of legume lectins are reviewed under subheads 3.2, 3.3 and 3.4.

\subsection{Antibacterial activity}

Antibacterial activity of lectins mainly attributed to their binding with carbohydrate components of the bacterial cell wall or extracellular glycans. Antibacterial lectins strongly interact with $N$-acetyl-Dacetylglucosamine (NAG), $N$-acetyl-D-muramic acid
(NAM), and tetrapeptide components of cell wall of gram-positive bacteria and with lipopolysaccharides (LPS) of gram-negative bacteria (Bourne et al. 1994; Ayouba et al. 1994; Qadir et al. 2013; Lagarda-Diaz et al. 2017). This interaction not only restricts the interaction of bacteria between the membrane and carbohydrate-binding proteins but also prevents penetration of the host cytoplasm (Mishra et al. 2019). Plant lectins cannot alter membrane structure and/or its permeability or disturb the metabolism of bacteria (Peuman and Van Damme 1995). Lectins from legumes Bauhinia variegata L. Dolichos lablab L., Trigonella foenumgraecum, Trifolium alexandrium L. and Delonix regia have shown antibacterial activity against some bacterial pathogens such as Mycobacterium rhodochrous, Bacillus cereus, Bacillus megaterium, Bacillus sphaericus, E. coli, Corynebacterium xerosis, Serratia marcescens and Staphylococcus aureus (Sammour and El-Shanshoury 1992). Gautam et al. (2018a) reported antibacterial activity of chickpea lectin against against E. coli, B. subtilis, S. marcescens and $P$. aeruginosa. El-Araby et al. (2020) reported the antibacterial activity of fava bean lectin, lentil lectin, and pea lectin against Klebsiella pneumonia, Staphylococcus aureus, Streptococcus mutants and Pseudomonas aeruginosa bacteria. Legume lectins have also been shown to inhibit bacterial biofilm formation (Islam and Khan 2012) and could be a potential candidate for the development of a non-antibiotic control measure of biofilm formation.

\subsection{Antifungal activity}

Plant lectins cannot bind with glycoconjugates present on fungal membranes or invade the cytoplasm of fungal cells due to the thick and rigid cell wall. However, indirect effects of lectin binding with cell wall components could affect fungal survival or other activities. For example, the binding of lectins with hyphae inhibits the growth of fungi, reduces nutrient absorption, and interferes with the spore germination process. The binding of lectins to the fungal cell wall also leads to swollen hyphae, vacuolization of cell content, and lysis of the hyphal cell wall. Chitinbinding lectins seem to play important role in plant defense against pathogenic fungi. In vitro studies have demonstrated that WGA (Wheat germ agglutinin) a chitin-binding lectin, inhibited the germination of fungal spore and hyphal growth of Trichoderma viride that confirms the antifungal action of chitin-binding lectins (Schlumbaum et al. 


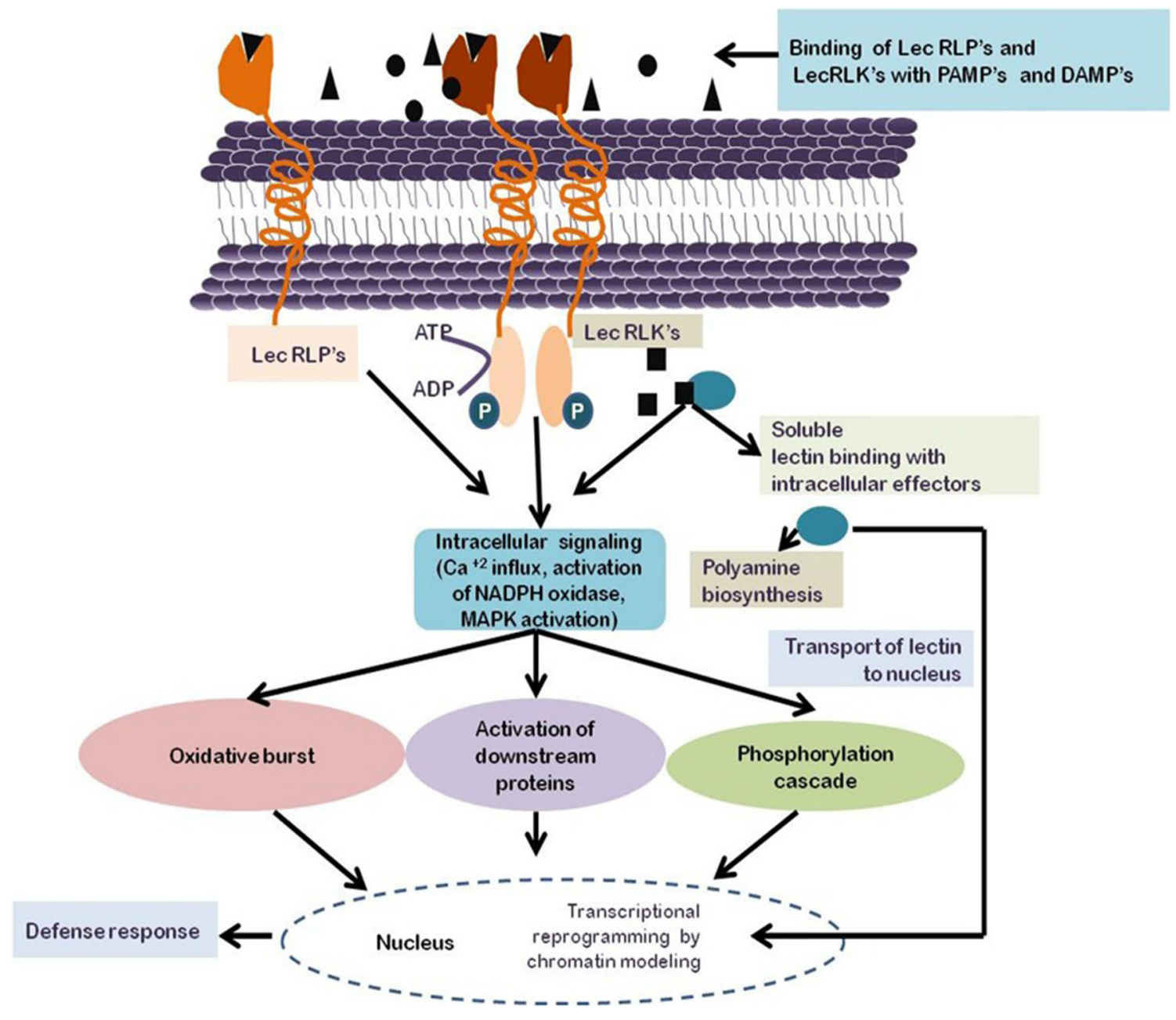

Figure 1. Lectin mediated signalling in plant defense. (The binding of lectin domains with PAMP's or DAMP's at cell surface starts an intracellular signaling pathway, which includes downstream proteins phosphorylation cascade, activation of transcription factors, and ultimately regulation of stress-responsive genes. Nucleocytoplasmic lectins bind with intracellular effectors and generate defense response).

1986). Although, this finding reported the antifungal activity of plant lectins, more definitive proof came from the study of Broekaert et al. (1989) who demonstrated the antifungal role of chitinase-free lectin from stinging nettle (Urtica dioica) against Botrytis cinerea, Trichoderma hamatum, and Phycomyces blakesleeanus. Till date, antifungal activity of various legume lectins has been well documented (Ye et al. 2001; Yan et al. 2005; Chen et al. 2009; Boleti et al. 2007; Sitohy et al. 2007; Qadir et al. 2013; Ang et al. 2014; Kumar et al. 2014; Gautam et al. 2018a; Elaraby et al. 2020).

\subsection{Antiviral activity}

The envelope of retroviruses and many other enveloped animal viruses is covered with glycoproteins. Antiviral activity of lectins depends on their ability to bind with complex glycans added as a result of post-translational modifications on viral envelope proteins which prevent interactions with host cells (Botos and Wlodawer 2003; Barton et al. 2014; Akkouh et al. 2015). Muller et al. (1988) for the first time reported that D-mannose specific lectin from Gerardia savaglia blocks HIV infection in $\mathrm{H} 9$ cells by preventing syncytium 
formation in HTLVIIIB/ H9-Jurkat cell system and HIV-1/human lymphocyte system. Several lectins from legumes suxh as Canavalia ensiformis (ConA), Lens culinaris (LCA), Vicia faba (VFA), Pisum sativum (PSA), Glycine max (SBA) and Phaseolus vulgaris (PHA-E) have also been found effective in inhibiting the interaction of the HIV virus with $\mathrm{CD}^{4+}$ cells through binding with glycoprotein gp-120 present on virus envelope (Lagarda-Diaz et al. 2017).

Lectins specificity to bind with mannose/glucose/NAcetyl glucosamine sugars has also been identified as a potent antiviral agent against coronaviruses (Keyaerts et al. 2007; Nascimento da Silva et al. 2020). SARScoronavirus spike proteins is heavily glycosylated and contain many $N$-glycosylation sites (Krokhin et al. 2003), therefore lectins having specificity to bind with glycans linked with spike protein may inhibit the growth of coronaviruses. Keyaerts et al. (2007) identified two targets for antiviral action of lectin against SARS-CoV. The first target was located early in the replication cycle, most probably viral attachment, and the second target was located at the end of the infectious virus cycle. They concluded that lectins probably interfere with the glycans on the spike protein during virus entry in the host cells and virus release, thus have inhibitory activity against coronaviruses.

In the last 14 to 15 months, we have witnessed the loss of thousands of lives worldwide due to the dissemination of a new type of coronavirus (SARS-CoV2, Covid-19). The first case of this novel coronavirus was reported from Wuhan, China in December, 2019. Since then, the virus has now been detected in different countries across the globe. The Covid-19 disease virus (SARS-CoV-2) is an enveloped virus covered with heavily glycosylated glycoproteins such as Spike protein (S-protein), Membrane protein (M-protein), Envelope protein (E-protein), and Nucleocapsid protein (N-protein) (Ahmed et al. 2020; Srivastava et al. 2021). These proteins have been identified to play a crucial role in SARS-CoV-2 virus pathogenesis in the host cells (Sternberg and Naujokat 2020; Verma et al. 2020). S-protein mediates virus entry in host cell through binding with human angiotensin-converting enzyme 2 (hACE2) and also interacts with host immune system (Ou et al. 2020; Vankadari and Wilce 2020; Walls et al. 2020; Luan et al. 2020). Besides structural proteins, glycosylated nonstructural proteins (3a protein), also determines the virulence of SARSCoV-2 (Fung and Liu 2018; Issa et al. 2020). Interaction of these glycoproteins of the SARS-CoV-2 virus with lectins should be in-depth investigated for their antiviral action against this deadly virus (Sohrab et al. 2020; Capell et al. 2020).

Recently, a glucose/mannose lectin from hyacinth bean (Lablab purpureus) [Flt3 receptor-interacting lectin (FRIL)], also known as DLL-I, was purified and investigated for its antiviral action against the SARSCoV-2 virus (strain hCoV-19/Taiwan/NTU04/2020) (Liu et al. 2020). The study revealed that FRIL at concentrations higher or equal to $6.25 \mu \mathrm{g} / \mathrm{ml}$ inhibited the cytopathic effect of the SARS-CoV-2 virus. Moreover, FRIL was able to bind with the N-glycosylated S-protein of the SARS-CoV-2 virus. FRIL also had antiviral activity against the influenza virus. The authors concluded that FRIL could have potential application in the treatment/prevention of Covid-19 and influenza disease (Liu et al. 2020). The encouraging results from the study, lectins from different sources should be investigated for their antiviral action against SARS-CoV-2 and other enveloped viruses (Nascimento da Silva et al. 2020).

\subsection{Anti-cancer activity}

The research interests in exploiting the potential of lectins as an anticancer molecule have increased in recent times (Gautam et al. 2020). The carbohydratemediated cell recognition; communication and adhesion are essential processes for tumor progression and metastasis in cancer. One of the important characteristics of cancer cells is that they display altered glycan structures on cell surfaces and can be explored to develop lectin-based tools for diagnostic and therapeutic research on cancer. Due to the carbohydratebinding specificity of lectin, lectins have become an important tool to study carbohydrate expression profiles of cancer cells, metastatic distribution patterns, and prognosis of lymphatic invasion (Brooks and Carter 2001; Konno et al. 2002). Fucosylation of proteins and lipids in tumor cells has been explored for the diagnosis of cancer (Miyoshi et al. 2012). Legume lectins exert anticancer activity by inducing caspaseindependent, and caspases and mitochondrial-dependent apoptosis pathways in cancer cells. Upon binding with glycoconjugates expressed on cancer cells, lectins increase the production of ROS (Reactive Oxygen Species) in cancer cells and result in their autophagic and apoptotic cell death (Mukhopadhyay et al. 2014; Panda et al. 2014). Moreover, the increased level of ROS in cancer cells also induces caspases and SEK/ JNK pathway and leads to programmed death of cancer 
cells (Polito et al. 2009). Lectin binding also increases the expression of tumor suppressor proteins (p38 ad p53) in cancer cells (Bantel et al. 1999; Lyu et al. 2002; Hostanska et al. 2003). Moreover, lectin binding also alters the signaling pathways involved in the expression of Fas, Bax, Bcl-XL and Bcl-2 proteins disrupts the mitochondrial membrane potential and leads to apoptosis through ROS induced p38-p53 pathway in mitochondria (Liu et al. 2009; Lam and Ng 2010). Amin et al. (2007) reported that ConA mediates p73dependent apoptosis in p53-null cells by inhibiting the Akt survival signaling and activating Foxo-Bim signaling. Lectin induced ER stress and UPR (Unfolded Protein Response) in cancer cells leads to up-regulation of IRE-1 $\alpha$, CHOP and activation of caspase 12 (Chan et al. 2012). Besides apoptosis, legume lectins also exert anticancer activity through autophagy (Bhutia et al. 2019). Chang et al. (2007) reported ConA mediated autophagy in hepatoma cells through activation of BNIP3-mitochondrial pathway in which BNIP3 depolarizes mitochondria, and increases ConA permeability to the mitochondrial surface, and initiates autophagy. Con A also induces autophagy in cancer cells by mediating PI3K/Akt/mTOR and MEK/ERK pathway (Roy et al. 2014). In addition to this, a proinflammatory cytokine, macrophage migration inhibitory factor (MIF), has been reported to play important role in ConA mediated autophagy (Lai et al. 2015). The anticancer activity of lectins from legumes such as Phaseolus vulgaris (Lam and $\mathrm{Ng}$ 2010; Fang et al. 2010, 2011; Chan et al. 2012, 2016; Ang et al. 2014; Wang et al. 2021), Phaseolus lunatus ( Wu et al. 2016), Cicer arietinum (Kumar et al. 2014; Gautam et al. 2018b), Abrus precatorius (Ramnath et al. 2009), Astragalus membranaceus (Huang et al. 2012), Astragalus mongholicus (Yan et al. 2009), Dioclea lasiocarpa (Gondim et al. 2017), Glycine max (Ye and Ng 2011; Panda et al. 2014), Sophora flavescens (Liu et al. 2008; Shi et al. 2014), Vicia faba (Jordinson et al. 1999), Lotus corniculatus (Rafiq et al. 2013), Bauhinia forficate (Silva et al. 2014), Bauhinia ungulata (Silva et al. 2013; de Sousa et al. 2016), Cratylia mollis (de Oliveira et al. 2017), Calliandra surinamensis (Procópio et al. 2017b), and Entada rheedii (Naik and Kumar 2020) have been well documented.

\subsection{Legume lectins and immune homeostatis}

Immune homeostasis is defined as the equilibrium state is maintained by a network of components of immune and adaptive system that continually monitor their environment, actively distinguishing between self and non-self, establishing cell-to-cell communication to protect from diseases (Crimeen-Irwin et al. 2005). The components of immune and adaptive system with specific functions and ability to produce and release molecules and exerts immuno-modulatory response. In addition to these components, different naturally occurring compounds can generate immunemodulatory responses. Studies have revealed that lectins have immune-modulatory activity, which include activation of Th1, Th2 or Th17 responses (Coelho et al. 2017). Lectins induce mitogenic effect by stimulating the proliferation of T-cells (Kilpatrick 1999). Mitogenic activity of lectins depends on their interaction with specific carbohydrates on T-cell surface receptors (TCR). Binding of lectins with TCR receptors releases secondary messengers and start downward signaling pathways such as increase in cytosolic $\mathrm{Ca}^{2+}$ levels, cytokines release, leading to immunomodulatory reaction. Lectins stimulate the synthesis of multiples clones of $\mathrm{T}$ cells, therefore considered as polyclonal mitogens. Interactions between lectins and $\mathrm{T}$ cells have been proved useful for analysis of biochemical events in T cell activation mechanism and its regulation (Sharon and Lis 2004). Upon mitogenic activation, T-cell produces high amount of cytokines, IL-2, IFN- $\gamma$ and TNF- $\alpha$. Lectin binding with surface receptors on T-cells triggered transmembrane signals which induce mitogenic effects on lymphocytes through increasing cytosolic $\mathrm{Ca}^{2+}$ concentration and ROS (Reactive Oxygen Species) production (de Melo et al. 2010) and TCR-dependent mechanism (de Melo et al. 2011) and lead to the proliferation of lymphocytes. PHA is the first mitogenic lectin (Teixeira et al. 2012). Cramoll and ConA lectins also showed high mitogenic activity in mice splenocytes in vivo (de Melo et al. 2011). Both PHA and ConA lectins have been used extensively for in vitro cell proliferation experiments. de Oliveira et al. (2011b, a) demonstrated immunomodulatory action of $\mathrm{ConBr}$, a lectin isolated from Canavalia brasiliensis seeds. ConBr was able to induce in vitro proliferation of splenocytes with minimal damage to the cellular structure. Furthermore, ConBr increased in the production of cytokines such as IL-2, IL-6 and IFN- $\gamma$ production and decreased IL-10. These findings indicate potential immunomodulatory effect of this lectin in conjunction with intrinsic role of carbohydrates in intercellular communication related to the inflammatory process. 
Table 1. Domain structure-based classes of lectin

\begin{tabular}{|c|c|c|c|c|}
\hline Lectin type & Structure & Example & PDBID & Reference \\
\hline Merolectin & & & $\begin{array}{c}\text { 1Q9B } \\
\text { (Hevein } \\
\text { Protein) }\end{array}$ & $\begin{array}{l}\text { Reyes- } \\
\text { Lopez et } \\
\text { al. }(2004)\end{array}$ \\
\hline Hololectin & & 5 & $\begin{array}{l}\text { 2PEL } \\
\text { (Peanut } \\
\text { Lectin) }\end{array}$ & $\begin{array}{l}\text { Banerjee } \\
\text { et al. } \\
(1996)\end{array}$ \\
\hline Chimerolectin & & 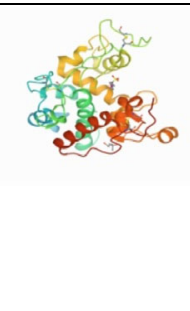 & $\begin{array}{c}\text { 3IWR } \\
\text { (Class I } \\
\text { chitinase } \\
\text { protein } \\
\text { from } \\
\text { Oryza } \\
\text { sativa L. } \\
\text { japonica) }\end{array}$ & $\begin{array}{l}\text { Kezuka et } \\
\text { al. (2010) }\end{array}$ \\
\hline Superlectin & & $\begin{array}{l}\text { TxLC-I lectin } \\
\text { (Tulip bulbs) }\end{array}$ & - & - \\
\hline
\end{tabular}

\subsection{Entomotoxic activity}

Due to the carbohydrate-binding specificity, many plant lectins have shown insectistatic and insecticidal activities. Artificial insect feeding assay with plant lectins has shown adverse effects on feeding behavior, fecundity, and growth and development of insects (Vandenborre et al. 2011). The extent and type of 
entomotoxic effects of lectin are dependent on various factors such as glycosylation pattern, insect species, and stage of development (Michiels et al. 2010). In the last few decades, insectistatic and insecticidal activities of plant lectins have been extensively investigated against agriculturally important insects.

Entomotoxic lectins are stable in a wide range of $\mathrm{pH}$ and able to resist proteolytic degradation in the insect gut. Insect feeding on plants releases lectin from disrupted plant structures and bind with different glycoconjugates and other structures in the insect midgut. Since the epithelial cell lining of the insect gut is directly exposed to lectins, therefore is the import target site of insecticidal lectins. The epithelial cells form peritrophic membrane covered with a grid-like network of glycoproteins and glycoprotein receptors containing glycan structures (Hegedus et al. 2009). The presence of glycan structures makes the peritrophic membrane a potential binding site for insecticidal lectins.

Interaction of lectins with glycan structures leads to disruption of epithelial cells lining in the insect gut, elongation of striated border microvilli, swelling of epithelial cells and increase the membrane permeability for harmful substances in hemolymph and affect the growth and development of insects (Majumder et al. 2005; Lagarda-Diaz et al. 2009; Vandenborre et al. 2011; Sprawka et al. 2015). Some lectins can pass through midgut epithelium and accumulate in fat body cells, hemolymph, ovarioles, and malpighian tubules (Powell et al. 1998a, b; Macedo et al. 2015). Lectin binding with secreted glycoproteins such as ferritin (Sadeghi et al. 2008) results in the formation of large complexes, therefore cannot diffuse back through the peritrophic membrane for being recycled in the digestive system. This results in leakage of digestive enzymes in the insect gut (Vandenborre et al. 2011). Several enzymes such as membrane-bound amino-peptidases, $\alpha$-amylases, $\alpha$ and $\beta$-glucosidases, $\beta$-subunit ATP synthase, clathrin heavy chain, HSP70, NADH quinone oxidoreductase, sarcoplasmic reticulum type calcium ATPase, sucrose, trypsin-like enzymes and vacuolar ATPase, are the other potential binding sites of lectins in insects (Macedo et al. 2015). Lectins also exert entomotoxic effects via induction of caspase-dependent apoptotic pathway in the insect gut (Sprawka et al. 2013, 2015; Tang et al. 2020).

Insect glycan structures are mainly high mannose and paucimannose-type, thus mannose/glucose binding lectins have a great interest as insectstatic and insecticidal lectins. A small number of complex glycan structures have also been identified in insect gut
(Michiels et al. 2010). The effect of lectins on the feeding behavior of insects is related to their binding with taste and olfactory receptors (Glycosylated integral membrane-spanning proteins), and interfere with their functioning or even initiates false signals to the nervous system (Michiels et al. 2010).

The entomotoxic nature of legume lectins was first reported for Phaseolus vulgaris lectin (PHA-E) by Janzen et al. (1976). They reported inability of bruchid bettle (Callosobruchus macualatus) to feed on black bean seeds (Phaseolus vulgaris L.). Artificial feeding assay with purified lectin showed inability of insects to survive at 5\% and even at $0.10 \%$ concentrations. They reported inability of bruchid bettle (Callosobruchus macualatus) to feed on black bean seeds (Phaseolus vulgaris L.). Gatehouse et al. (1984) also reported insecticidal property Phaseolus vulgaris lectin (PHA). Numerous legume lectins have been investigated for entomotoxic activity against different insects (table 2).

It has been observed that some plant lectins exhibit entomotoxic activity against a particular insect while other posses broad insecticidal action against insect belong to different orders. Since different insects have very low $\mathrm{pH}$ (strongly acidic) to a very $\mathrm{pH}$ (alkaline) in midgut, therefore entomotoxic lectins must have capacity to resist the hostile environment in insect midgut (Vandenborre et al. 2011). Another important factor associated with the variable entonotoxic action of lectins is their ability to resist proteolytic degradation in insect midgut (Zhu-salzman et al. 1998). Insects have their own proteolytic machinery and for exerting entomotoxic effect, lectins must be able to resist proteolytic degradation in insect midgut (Felton 2005). It is a well-known fact that the lectins have specificity in binding with carbohydrate moieties, therefore different lectins will interact differentially to target sites in the insect midgut. This can be understand by the action of wheat germ agglutinin (WGA) which is not toxic to pea aphid (Acyrthosiphon pisum) which lacks a functional peritrophic membrane, while GNA and ConA lectins exert entomotoxic activity against this insect (Rahbe et al. 1995). Since glycosylation patterns in insect midgut change depending on the developmental stage or other factors, the binding of lectin may differ in insect gut (Aoki et al. 2007; Michiels et al. 2010; Vandenborre et al. 2011). Some plant lectins have entomotoxic effects at larval stage and some of them have at adult stage (Vandenborre et al. 2011). For example, Pisum sativum agglutinin has shown entomotoxic effects only on larvae of pollen beetle, not on adults (Melander et al. 2003). 
Table 2. Entomotoxic classes of legume lectins

\begin{tabular}{|c|c|c|}
\hline Legume lectins & Insect & Reference \\
\hline & Acyrthosiphon pisum & $\begin{array}{l}\text { Rahbe and Febvay (1993), Sauvion et al. (2004a), } \\
\text { Sauvion et al. (2004b) }\end{array}$ \\
\hline \multirow[t]{8}{*}{ ConA } & Bactericera cockerelli & Tang et al. (2020) \\
\hline & Helicoverpa armigera & War et al. (2013) \\
\hline & Lacanobia oleracea & $\begin{array}{l}\text { Fitches and Gatehouse (1998), Gatehouse et al. } \\
\text { (1999), Fitches et al. (2001a) }\end{array}$ \\
\hline & Meligethes aeneus & Melander et al. (2003) \\
\hline & Myzus persiacae & Sauvion et al. (1996), Gatehouse et al. (1999) \\
\hline & Rhopalosiphum padi & Sprawka et al. (2015) \\
\hline & Sitobion avenae & Sprawka et al. (2014) \\
\hline & Tarophagous proserpina & Powell (2001) \\
\hline \multirow[t]{3}{*}{ PSA } & Heliothis virescens & Boulter et al. (1990) \\
\hline & Meligethes aeneus & Melander et al. (2003) \\
\hline & Tarophagous proserpina & Powell (2001) \\
\hline PTA & Nilaparvata lugens & Powell (2001) \\
\hline GSL & Callosobruchus maculatus & $\begin{array}{l}\text { Zhu-Salzman et al. (1998), Zhu-Salzman } \\
\text { and Salzman (2001) }\end{array}$ \\
\hline \multirow[t]{3}{*}{ BmoLL } & Anagasta kuehniella & Macedo et al. (2007) \\
\hline & Callosobruchus maculatus & \\
\hline & Zabrotes subfasciatus & \\
\hline Pf2 lectin & Zabrotes subfasciatus & Lagarda-Diaz et al. (2009) \\
\hline \multirow[t]{4}{*}{ PHA } & Callosobruchus maculates & Gatehouse et al. (1984) \\
\hline & Lygus Hesperus & Habibi et al. (2000) \\
\hline & Lacanobia oleracea & Fitches et al. (2001b) \\
\hline & Sitobion avenae & Sprawka et al. (2013) \\
\hline BPA & Ostrinia nubilalis & Czapla and Lang (1990) \\
\hline \multirow[t]{2}{*}{ PNA } & Helicoverpa armigera & Shukla et al. (2005) \\
\hline & Callosobruchus maculatus & Murdock et al. (1990) \\
\hline Pigeon pea lectin & Helicoverpa armigera & Arora et al. (2005) \\
\hline Chick pea lectin & Helicoverpa armigera & Shukla et al. (2005) \\
\hline
\end{tabular}

\section{Carbohydrate specificities of legume lectins}

One of the important features of legume lectins is that they are storage proteins synthesized as inactive precursor proteins with a signal peptide. Their biosynthesis starts on membrane-bound ribosomes or polyribosomes in the cytosol. Targeting of these proteins to the endoplasmic reticulum is mediated by the signal sequence present at the $N$-terminus of the growing polypeptide chain. As the polypeptide chain elongates, the signal peptide is removed co-translationally by the signal peptidase enzyme. The polypeptide chain releases into ER lumen. Glycosylation is an important post-translational modification that ensures proper folding and functioning of proteins. $\mathrm{N}$ linked glycosylation occurs at consensus sequences (Asn-X-Ser/Thr) where $\mathrm{X}$ is any amino acid except proline. The extent of glycosylation confers stability to proteins. Most of the legume lectins are glycosylated with mannose type and complex-type glycans. Some lectins such as PHA-E are glycosylated with mannose type and complex-type glycans. Differences in glycosylation patterns result in the formation of different glycoforms (Van Damme et al. 1998).

After glycosylation, they accumulate in protein storage bodies in seeds (De Hoff et al. 2009) where some proteolytic events occur such as removal of C-terminal propeptide (Vitale et al. 1984) and generation of $\beta$-chain ( $\mathrm{N}$-terminus) and $\alpha$-chain $(\mathrm{C}$-terminus) (Lioi et al. 2006). The association of these chains forms dimers; they are then proteolytically processed to form tetramers containing two separate $\alpha$ and $\beta$ chains. The trimming of the C-terminal of the polypeptide is a common event in legume lectin biosynthesis and also responsible for the generation of lectin isoforms (Rabijns et al. 2001; Loris et al. 2003). Besides fulfilling the role of storage proteins, seed lectins also have a crucial role to play during plant defense (Chrispeels and Raikhel 1991). Lectins are also localized to vegetative tissues such as roots, nodules, bud, and bark in smaller amounts (De Hoff et al. 2009). They show considerable sequence 
similarity with seed lectins. For example, DB58 lectin from Dolichos biflorus stem and leaf lectin share sequence similarity with $D$. biflorus seed lectin (Schnell and Etzler 1988).

Typically, the primary structure of legume lectins are protomers made up of 250 to 300 amino acid residues ( $\sim 25$ to $30 \mathrm{kDa}$ ) and show evolutionary conservedness (Wales et al. 1991). Most of the legume lectin promoters can give rise to single-chain lectins which don't have cleavable sites (PHA, ConA, SBA). In some instances, the protomers are proteolytically processed and produce two chains, $\beta$-(N-terminal, large) and $\alpha$ (C-terminal, short), thereby usually referred to as two chain lectins (Vicia faba lectin and Pisum sativum lectin). Most, but not all, are glycosylated and carry up to three asparagine-linked oligosaccharides per subunit (Van Damme et al. 1998). The conserved amino acids include several of those that participate in hydrogen bonding or hydrophobic interactions with the monosaccharide held in the combining site and almost all residues that coordinate the metal ions. Primary structure analysis of legume lectin also reveals high conservedness in the ligand-binding sites. The analysis of primary sequences of legume lectins is the best way to investigate evolutionary relatedness, to predict their processing pathway, to study folding patterns, and to investigate carbohydrate-binding specificity of lectins.

The dominance of $\beta$-strands is an important characteristic of the secondary structure of legume lectins. Legume lectins have higher proportion of $\beta$-sheets, $\beta$ turns, and negligible amount of $\alpha$-helix in their secondary structure (Swamy et al. 1985), thus considered as $\beta$-sheet proteins. The structural components of the secondary structure have implications in the analysis of the 3D structure of legume lectins. ConA was the first lectin for which a high resolution crystallographic structure was resolved (Edelman et al. 1972; Hardman and Ainsworth 1972). Since then 3D structures for different legume lectins have been also elucidated (table 3).

In general, the 3D structure of legume lectins consists of flat six-stranded anti-parallel $\beta$-sheets (Back face) and seven-stranded curved anti-parallel $\beta$ sheets (front face), interconnected by several loops (figure $2 \mathrm{a}$ ). Nearly $50 \%$ of amino acid residues are present in loops. The negligible amount of $\alpha$-helix is one of the important features of the structure of legume lectins. The folding patterns of secondary and tertiary structures of legume lectins are superimposable to each other. The dome-like structure represents the $\beta$-sandwich structure, structurally related to the 'Jelly roll fold' (Stirk et al. 1992) also known as lectin fold (Srinivasan et al. 1996) with two hydrophobic cavities, formed between the front and back $\beta$-sheets and between curled loop and front $\beta$ sheets. The concavity in front $\beta$-sheets and a second hydrophobic core formed carbohydrate-binding domain is well suited to be bind with carbohydrates. Legume lectins require divalent cations particularly $\mathrm{Ca}^{+2}$ and $\mathrm{Mn}^{+2}$ for their activity as they are essential for maintaining the stability of the carbohydratebinding site. Amino acids involved in the formation of the metal-binding site namely glutamic acid, aspartic acid, and histidine in legume lectins are conserved (Rini 1995).

The carbohydrate and metal-binding sites are localized in close vicinity at the top of the front sheet in the 3D structure (Cumming et al. 2017). In legume lectins structure, four loops, i.e., A, B, C, and $\mathrm{D}$ are responsible for the formation of CRD (Carbohydrate Recognition Domain) (Sharma and Surolia 1997; Benevides et al. 2012). The four conserved amino acids in loops are essential for binding with carbohydrates (figure 2b). Aspartic acid residue in loop A forms hydrogen bonds between its side chain and carbohydrate ligand. The binding of two metal ions is stabilized by four water molecules (Adar et al. 1998). Isomerization of trans peptide bond to the cis orientation between alanine and aspartic acid residues is necessary for proper orientation of asparagine and arginine residues in carbohydrate bonding site that further stabilized the carbohydrate-binding site. The formation cis peptide bond is driven by the binding of metal ions. In loop $\mathrm{C}$, asparagine via amide group forms a hydrogen bond with the hydroxyl group of the binding sugar (Cummings et al. 2017). Some legume lectins also have a hydrophobic cavity, which is responsible for their non-covalent interactions with non-carbohydrate ligands. Binding with non-carbohydrate ligands don't have any influence on the carbohydrate-binding specificity of lectins and also leads to their diverse biological functions (Srinivas et al. 2000). Various legume lectins have been identified to be specific to galactose, $N$-acetyl-D-galactosamine, mannose, glucose, $N$-acetyl-D-glucosamine, fucose, and more complex carbohydrate structures. Variability in the conformation and size of $\mathrm{C}$ and D loops determines carbohydrate-binding specificity of lectins (Sharma and Surolia 1997; Rao et al. 1998). A complex network of hydrogen bonding, hydrophobic interactions, Vander Waal's forces, and metal ion co-ordination bonding determines the carbohydrate-binding specificity of lectins. 
Table 3. Carbohydrate specificity and PDBID of some important legume lectins

\begin{tabular}{|c|c|c|c|c|}
\hline Legume lectins & Legume source & Carbohydrate specificity & PDBID & Reference \\
\hline BFL & Bauhinia forficata & GalNAc & $5 \mathrm{~T} 52$ & Lubkowski et al. (2017) \\
\hline ConA & Canavalia ensiformis & Glu, Man & $113 \mathrm{H}$ & Sanders et al. (2001) \\
\hline $\mathrm{ConBr}$ & Canavalia brasiliensis & Glu, Man & 3JU9 & Bezerra et al. (2011) \\
\hline Cramoll & Cratylia mollis & Glu, Man & $1 \mathrm{MVQ}$ & de Souza et al. (2003) \\
\hline DBL & Dolichos biflorus & GluNAc & 1LUL & Hamelryck et al. (1999) \\
\hline DBL (Vegetative) & Dolichos biflorus & GluNAc & $1 \mathrm{G} 7 \mathrm{Y}$ & Buts et al. (2001) \\
\hline DLL & Dolichos lablab & Gal & 3UJO & Shetty et al. (2013) \\
\hline DvirL & Dioclea virgata & Glu, Man & 3RS6 & Nóbrega et al. (2012) \\
\hline ECA & Erythrina cristagalli & Gal, GalNac & $1 \mathrm{GZC}$ & Svensson et al. (2002) \\
\hline EcoL & Erythrina corallodendron & Gal, GalNac & $1 \mathrm{AXZ}$ & Shaanan and Elgavish (1998) \\
\hline FRIL & Lablab purpureus & Glu, Man & 1QMO & Hamelryck et al. (2000) \\
\hline GSL I & $\begin{array}{l}\text { Griffonia simplicifolia } \\
1-B 4\end{array}$ & Gal & 1HQL & Tempel et al. (2002) \\
\hline GS IV & Griffonia simplicifolia IV & Fuc & $1 \mathrm{GSL}$ & Delbaere et al. (1993) \\
\hline LCA & Lens culinaris & Fuc & $1 \mathrm{LEN}$ & Loris et al. (1994) \\
\hline LTL & Lotus tetragonolobus & Fuc & $2 \mathrm{EIG}$ & Moreno et al. (2007) \\
\hline MAL & Maackia amurensis & Gal, Sialic acid & $1 \mathrm{DBN}$ & Imberty et al. (2000) \\
\hline PHA & Phaseolus vulgaris & GluNAc & $3 \mathrm{WCS}$ & Nagae et al. (2014) \\
\hline PNA & Arachis hypogaea & Gal, GalNAc & 1V6I & Kundhavai Natchiar et al. (2004) \\
\hline PSA & Pisum sativum & Glu, Man & 2LTN & Prasthofer et al. (1989) \\
\hline $\mathrm{RPbAI}$ & Robinia pseudoacacia & GalNAc & $1 \mathrm{FNY}$ & Rabijns et al. (2001) \\
\hline SBA & Glycine $\max$ & GalNAc & $1 \mathrm{SBF}$ & Olsen et al. (1997) \\
\hline TCLL & Tamarindus indica & GluNAc & 4B16 & Patil et al. (2013) \\
\hline UEA-I & Ulex europeus & Fuc, $\alpha-1,2-F u c$ & 1QNW & Loris et al. (2000) \\
\hline UEA-II & Ulex europeus & GluNAc & 1QNW & Loris et al. (2000) \\
\hline VFA & Vicia faba & Glu, Man & 2B7Y & Reeke and Becker (1986) \\
\hline WFA & Wisteria floribunda & GalNAc & $5 \mathrm{KXB}$ & Haji-Ghassemi et al. (2016) \\
\hline VML & Vatairea macrocarpa & GalNAc & $4 \mathrm{U} 2 \mathrm{~A}$ & Sousa et al. (2015) \\
\hline SPL & Spatholobus parvifl orus & Gal & 3IPV & Geethanandan et al. (2011) \\
\hline
\end{tabular}

The quaternary structure of legume lectins is characterized by an oligomeric structure in which lectin monomers are assembled as homodimers (Canonical legume lectin dimer) or homotetrameric structure (dimmers of dimers) (Lagarda-Diaz et al. 2017). Moreover, heterotetrameric structures have also been observed. Hydrophobic interactions, hydrogen bonds, disulfide, and salt linkages are the main forces maintaining the structure of legume lectins (Sharma and Surolia 1997; Manoj and Suguna 2001). Typically different types of quaternary structures are known for legume lectins [Canonical, ECorL-type, GS4-type, DBL-type, ConA-type, PNA-type, GS1-type, and DB58-type and Arcelin-5-type (monomeric) structures]. The difference between the protomers of legume lectins lies in $\beta$-chain structure corresponds to $\mathrm{C}$-terminal in which 12 amino acid residues become truncated. The presence of the $\alpha$-helix at the C-terminal is responsible for the joining of two protomers and stabilization of the structure.
The interaction of proteins with carbohydrates has always been an interesting area of research for biologists for having a deep understanding of myriad of biological processes such as cell-cell recognition and disease resistance (Van Holle et al. 2017). Legume lectins owing to their specific carbohydrate binding have provided a model system for glycobilogists understanding molecular basis of these biological processes. They have also been used for the purification and characterization of complex carbohydrates and glycoconjugates. The carbohydrate specificity of some legume lectins to different carbohydrates is presented in table 3.

Studies have revealed that the interaction of hydroxyl groups of sugars to the amino acid side chains via hydrogen bonding and hydrophobic forces is required for lectins binding with carbohydrates. Interactions with these hydroxyl groups serve function of orienting sugar molecules in binding site (Drickamer 1997). The tertiary structures of lectins bound with their bound 

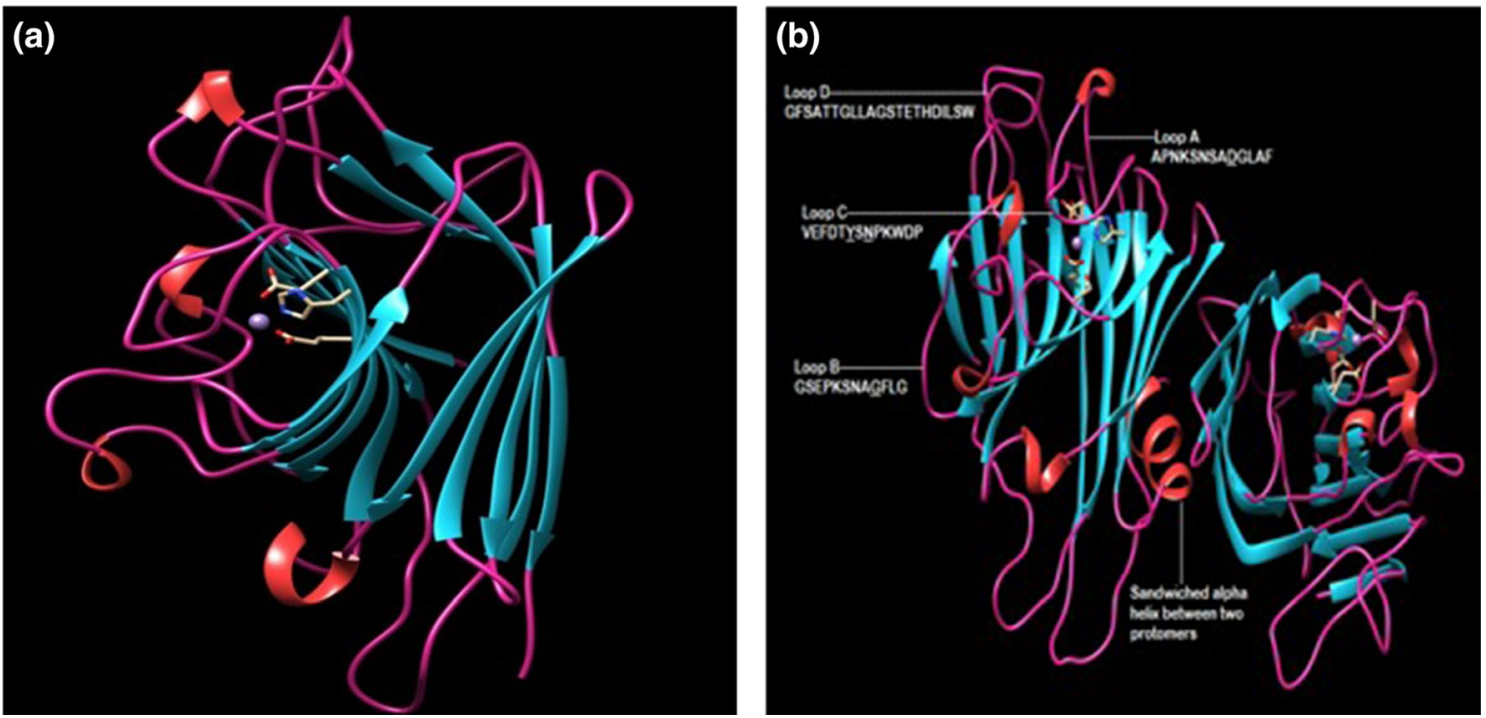

Figure 2. (a) Tertiary structure of Vigna unguiculata lectin; (b) carbohydrate binding loops in dimeric structure of Vigna unguiculata lectin and corresponding amino acid sequence of each loop (Conserved amino acid residues in each loop are underlined).

sugar ligands and mutational studies revealed conserved triad of amino acids residues (Asp, Gly/Arg, Asn) responsible for carbohydrate binding. All of them bind the monosaccharide through main chain amides and not through their side chain residues. The substitution of either Aspartic acid or Asparagine in several legume lectins resulted in loss of sugar binding activity (Adar and Sharon 1996). In addition to this a conserved aromatic residue (Phenyl alanine/Tryptophane /Tyrosine) in primary binding site is involved in sugar stacking interactions. In legume lectins, specific to $\mathrm{D}$-galactose or D- $\mathrm{N}$-acetyl glucosamine oxygen in the side chains of aspartic acid residue are hydrogen bonded to the $\mathrm{C} 3-\mathrm{OH}$ and $\mathrm{C} 4-\mathrm{OH}$ group of monosaccharide while amide chain of glycine make hydrogen bond only with C3-OH group (Sharon and Lis 2002). Further, an aromatic amino acid is required for the stacking of the hydrophobic face of the sugar. Aspartic acid and amide of asparagine coordinate with $\mathrm{Ca}^{2+}$ present in all legume lectins, which helps to position these residues in the correct place at the sugar binding site (Lis and Sharon 1998). $\mathrm{Ca}^{2+}$ and $\mathrm{Mn}^{2+}$ ions present in all legume lectins are coordinated via the carboxyl group of the two conserved Aspartic acid residues. Binding of the two metal ions is further stabilized by four water molecules. The presence of a rare cis-peptide bond between the conserved Aspartic acid of the triad and the preceding amino acid, which is almost always alanine is an added characteristic (Sharon and Lis
2002). The cis-peptide bond is required for the proper orientation of Asp in the combining site. The structure of metal binding region plays a major role in determining sugar specificity of lectins (Yamamoto et al. 2000). Differentiation between galactose and mannose by legume lectins is due to the differential orientation of the ligand.

In mannose/glucose lectins like ConA (Derewenda et al. 1989), LOL-I (Lathyrus ochrus Isolectin) (Bourne et al. 1990) and lentil lectin (Loris et al. 1994), galactose and mannose are oriented in a way such that the carboxyl oxygens of Asp are $\mathrm{H}$-bonded to 6-OH and 4-OH of the sugars and amide of the asparagine side chain is hydrogen bonded to the 4-OH. In addition, the main chain amide of glycine, forms H-bonds with 3-OH. In contrast, in galactose specific lectins like ECorL (Adar and Sharon 1996), SBA (Dessen et al. 1995), and PNA (Banerjee et al. 1996), Aspartic acid oxygens form hydrogen bonds with $4-\mathrm{OH}$ and $3-\mathrm{OH}$ and amide of Asparagine and Glycine to 3-OH. Therefore, legume lectins, conserved amino acid triad, stabilized and positioned by metal ions or water molecules, responsible for binding of diverse monosaccharides (Sharon and Lis 2002). Using Ligplot analysis, the carbohydrate binding specificity analysis of rice bean lectin $(\mathrm{RbL})$ revealed that $\mathrm{C} 3-\mathrm{OH}$ and $\mathrm{C} 4$ $\mathrm{OH}$ groups of galactose sugar were hydrogen bonded to oxygen groups of aspartic acid ${ }^{112}$ residue (OD1 and OD2) with $2.56 \AA$ and $2.84 \AA$ bond length while 
glycine ${ }^{130}$ via $\mathrm{NH}$ group was hydrogen bonded to C3$\mathrm{OH}$ with $2.84 \AA$ bond length (Katoch 2020). The presence of Tyrosine ${ }^{154}$ amino acid residue fulfilled the function of stacking of hydrophobic face of the sugar. In addition, leucine ${ }^{241,242}$ via their amino group were hydrogen bonded to the C6-OH group with $3.04 \AA$ and $2.84 \AA$ bond lengths. N-acetyl-D-glucosamine sugar interacted with rice bean lectin via two hydrogen bonds between with the oxygen's of aspartic acid side chains and $\mathrm{C} 6-\mathrm{OH}$ and $\mathrm{C} 4-\mathrm{OH}$ groups of the sugar. The amide side chains of asparagine ${ }^{156}$ and glycine ${ }^{130}$ residues were involved in hydrogen bonding with $\mathrm{C} 4-\mathrm{OH}$ and C3-OH group of the sugar (Katoch 2020).

Lectins exhibit higher affinity towards oligosaccharides suggesting occurrence of additional interactions with parts of the ligand located outside monosaccharide binding site (Loris et al. 1998). Higher affinity of ECorL for lactose is attributed to hydrogen binding between amide group of Glutamine ${ }^{219}$ and 3-OH of glucose moiety of disaccharide along with interaction of Galactose with conserved amino acid triad in primary binding site. Mutagenesis of Gln219 of ECorL (Adar and Sharon 1996) and refined 3D structure of ECorL-Lac complex revealed the importance of hydrogen bonding between a glutamine residue and glucose moiety in addition to triad was responsible for high affinity of lectin to lactose (Elgavish and Shaanan 1998). LigPlot analysis also revealed lactose as a putative ligand for rice bean where asparagine ${ }^{156}$, glycine $^{130}$, tyrosine ${ }^{156}$ and leucine ${ }^{241,242}$ have been found to be involved in hydrogen bonding with hydroxyl groups of the sugar (Katoch 2020).

In addition to carbohydrate binding sites, some lectins such as, Lima bean lectin (Roberts and Goldstein 1983), Dolichos biflorus lectin (Gegg et al. 1992), Winged bean lectin (Srinivas et al. 2000) and Dolichos lablab lectin (Shetty et al. 2013) have been reported to posses binding sites for hydrophobic ligands. The presence of additional binding sites suggested other physiological roles of lectins. Using Galaxy site web server, we also observed an additional adenine-binding site constituted by four hydrophobic amino acids (Leucine $^{192}$, Threonine $^{194}$, Valine ${ }^{203}$ and Isoleucine ${ }^{216}$ ) in rice bean lectin (Katoch 2020). The presence of adenine binding site in rice bean lectin suggested its physiological role in plant hormone regulated growth and development of plant. Further, adenine is also a component of ATP therefore binding of rice bean lectin to ATP can be speculated (Katoch 2020). Delatorre et al. (2007) reported that the additional adeninebinding site supports the role of lectins in plant defence mechanism. Since metal ions are required for the stabilization of the carbohydrate binding site in legume lectins, binding site for $\mathrm{Ca}^{+2}$ ion formed by side chains of $\mathrm{Glu}^{150}$, $\mathrm{Asp}^{152}$, $\mathrm{Asp}^{160}$, His ${ }^{165}$ amino acid residues have also been predicted for rice bean lectin in our laboratory using GalaxySite Web server.

Legume lectins are closely related proteins and share high sequence similarity that denotes their conserved nature during evolution (Lioi et al. 2006; Gautam et al. 2018a) to preserve their biological functions (Pinto et al. 2008). Therefore, they have been stressed as a useful tool to study evolutionary and phylogenetic relationships. Sometimes, the presence of isoforms of legume lectins due to microheterogeneity in amino acid sequences has been reported which indicates their probable encoding by the family of tandemly linked genes (Peumans et al. 2001; Pinto et al. 2008). In some tetrameric lectins (Phytohemagglutination from Phaseolus vulgaris), the polypeptide chains are encoded by two tandemly linked genes and share about $90 \%$ similarity (Chrispeels and Raikhel 1991). In soyabean, more than one lectin genes have been detected among which only a single gene produces a single functional polypeptide. The other lectin genes may be pseudogenes originating from the process of gene duplication (Galasso et al. 2004). In some other legumes such as Griffonia simplicifolia, two or more seed lectins with different carbohydrate specificities and amino acid sequences are encoded by different genes or small families of genes. There are some examples of legumes in which seed and vegetative lectins are encoded by different genes. Robinia pseudoacacia contains two distinct seed lectins and three different bark lectins that are encoded by different genes (Van Damme et al. 1995).

Although the presence of intronless genes is a characteristic feature of prokaryotic cells, several intronless genes have been identified in eukaryotes. The presence of intronless genes in eukaryotes, provide tools to make comparison among different genomes and evolutionary relationships. Most of the characterized legume lectin genes are devoid of intervening sequences, including Canavalia ensformis lectin (Carrington et al. 1985; Min et al. 1992) and Canavalia gladiata lectin genes (Yamauchi and Minamikawa 1990). Filho et al. (2017) analyzed 35 legume lectin gene sequences and revealed that all sequences are composed of a single exon and have no introns. Vodkin et al. (1983) also reported that Lel from soyabean encodes almost $1 \mathrm{~kb}$ long mRNA and contains no introns. Similarly, Hua et al. (2015) also reported the intronless nature of a novel gene related to legume lectins from Salvia miltiorrhiza Bunge. D'Onofrio 
et al. (1991) suggested that the presence of an intronless gene might be a structural feature that is maintained because it provides a selective advantage by rapidly encoding turning over transcripts to respond without significant delay to various exogenous signals. Since splicing is not required, very little time would elapse between transcription and accumulation of mature mRNA in the cell. The intronless nature of the legume lectins gene may be one of the reasons for their high concentrations in seeds.

\section{Technological advances involving legume lectins}

\subsection{Lectin blotting}

Glycosylation is essential for maintaining the structural and functional integrity of proteins. It also plays a crucial role in many essential biological processes for example cell-cell interactions and protein targeting (Cao et al. 2013). Studies have revealed that the alteration in glycosylation pattern or glycan profile is an important characteristic of the pathophysiological state of cells. Thus, decoding information in glycosylation pattern is essential for the diagnosis and treatment of diseases. Lectins are considered an important glycan deciphering molecule due to their carbohydrate specificity. Lectin blotting is an effective technique for lectin-mediated characterization of glycans linked with proteins and lipids. The working principle of the lectin blotting technique is similar to western blotting in which probed or labeled lectins are used in place of labeled antibodies (Shan et al. 2001; Hashim et al. 2017). The steps in lectin blotting include electrophoretic separation of glycoproteins, transfer of proteins to the nitrocellulose membrane, membrane incubation with biotinylated lectins, and detection with the streptavidin-enzyme conjugate. Lectin blotting is an effective tool in glycan analysis (Norton et al. 2016; Vainauskas et al. 2016).

\subsection{Legume lectins-based biosensors}

Interaction between protein and carbohydrates plays a crucial in different biological processes such as cell-cell interactions, cell signaling as well as host-pathogen interaction. Legume lectins, owing to their vast diversity in carbohydrate-binding specificity, are potential candidates to develop optical and electrochemical biosensors Klukova et al. 2016). Moreover, legume lectin-based biosensors could be a fast and cost- effective alternative to antibodies and nucleic acids based biosensors (Luna et al. 2014).

Among legume lectins, the specificity of ConA lectin with glucose/mannose sugars has been explored in the development of biosensors for different applications such as detection of virus and bacteria as well as profiling of serum glycoproteins and cell surfaces glycoproteins. An electrochemical biosensor based on ConA lectin has also been developed for the non-enzymatic recognition of glucose (Li et al. 2011). An electrochemical biosensor based on ConA and gold nanoparticles-modified electrode has been developed to recognize serum glycoproteins from patients infected by norovirus (Hong et al. 2015) and dengue virus, zika virus, chikungunya virus and yellow fever virus (Simao et al. 2020). Ma et al. (2015) developed a label-free lectin biosensor for the quantitative measurement of the interaction between lipopolysaccharide (LPS) on Gramnegative bacteria and immobilized ConA. Yaghoubi et al. (2020) developed ConA coupled silicon-based biosensor for the detection of bacteria. Biosensors based on Cramoll lectin and BmoLL lectin have been developed for dengue virus serotypes detection (Oliveira et al. 2011a, b; Andrade et al. 2011; Avelino et al. 2014). The glycan-binding specificity of lectins could also be used to develop biosensors for fast detection of coronavirus including SARS-CoV-2 (Nascimento da Silva et al. 2020).

\subsection{Legume lectins-based drug delivery system}

Lectins have been used as a medium for targeted delivery of drugs. The basis of lectin-mediated drug targeting is that most of the cell surface proteins and many membrane lipids are attached with glycans and serve as binding ligands for lectins. Different cells alter their glycan profile or express different glycan profiles in response to pathological states. Lectins owing to their specific carbohydrate-binding provide a great means to target drugs specifically to various cells and tissues that are in a pathological state (Gavrovic-Jankulovic and Prodanovic 2011). Moreover, the internalization via receptor-mediated endocytosis in cells promotes drug uptake actively by the cells. Cai and Zhang (2005) evaluated the cytotoxicity of PNA lectin with 5-fluorouracil (5-Fu) derivative on LoVo cells. Jain and Jangdey (2009) used ConA lectin-mediated delivery system of drug clarithromycin for effective treatment of colonization of Helicobacter pylori. Ikemoto et al. (2016) evaluated liposomes covered with Bauhinia purpurea agglutinin as a drug delivery 
system to treat human prostate cancer. The study reported that binding of the delivery system with DU145-cells in mice resulted in and suppression of the growth of the cells.

\subsection{Lectin affinity chromatography}

Lectin affinity chromatography is an important method for glycoconjugates purification (Hashim et al. 2017). This chromatography based on fact that carbohydrate moieties present on glycoconjugates interact with immobilized lectin on matrix via hydrogen bonding, hydrophobic, electrostatic and van der Waals interactions (Monzo et al. 2007). Various legume lectins are frequently used for affinity chromatography of glycoconjugates (Monzo et al. 2007). Sumi et al. (1999) differentiated carcinoma and prostatic hyperplasia through differences in the carbohydrate structures of the prostate-specific antigen (PSAg) using lectin affinity chromatography. They used a consecutive series of columns with immobilized ConA, PSA, WGA, phytohemagglutinin E4 (PhHA-E4) and phytohemagglutinin L4 (PhHA-L4). Durham and Regnier (2006) used the combination of ConA (specific to mannose) and Artocarpus altilis lectin (specific to GalNAc in $O$ glycosylated and Man-containing sites of $N$-glycans) to isolate $O$-glycosylated peptides while investigating $O$ glycosylation sites of human serum proteins. This chromatographic technique has potential for analyzing and identifying site-specific glycosylation of many proteins in combination with mass spectroscopy (Mishra et al. 2019).

\subsection{Lectin arrays}

In the last few decades, methods based on mass spectrometry have been used extensively in glycome research (Satomaa et al. 2009). Although widely used, there are some concerns regarding the utilization of MS (Mass Spectroscopy) based methods in glycome research, such as the release of glycans from glycoconjugates which brings error in profiling of glycans (Dell and Morris 2001). Moreover, MS-based glycan profiling methods require complex sample preparation. For linkage analysis of glycans, NMR spectroscopy has been proved a powerful tool but has the limitation of availability of substantial quantities of homogeneous samples. Lectin arrays have provided a good alternative to MS-based methods of glycan profiling. This technology involves the utilization of densely immobilized lectins on a solid support for the profiling of glycoconjugates (Dang et al. 2020). Lectin array is a simple, rapid, and sensitive technique in comparison to MSbased methods. Unlike to MS-based methods, removal of glycan from glycol conjugates is not required in the lectin array technique, therefore lectin arrays is an efficient technique to analyze and differentiate the glycomic profile of samples. Lectin arrays technique has been used for glycophenotyping of different bacteria, profiling of biomarkers of different diseases, and expression pattern analysis of glycogenes (glycosyltransferases, sulfotransferases, and sugar-nucleotide transporters) (Katrlik et al. 2010).

\subsection{Legume lectins histochemistry}

Generally, lectin histochemistry uses labeled lectins as potential markers for altered glycans moieties on tissue and cells, which are in a pathological state. Direct and indirect methods have been used to generate conjugate lectins. In the direct method, lectins are covalently linked to fluorophores, enzymes (Horseradish peroxidase), colloidal gold, or ferritin (Sobral et al. 2010; Leal et al. 2012; Hashim et al. 2017). In the indirect method, lectin is labeled with biotin, which is recognized by enzyme-linked streptavidin. Lectin histochemistry has become an efficient approach to study alteration in the glycosylation pattern of normal and cancer cells (Marafioti et al. 1994; Nishimura et al. 2000; Beltrão et al. 1998; Beltrão et al. 2003; Sobral et al. 2010; Coelho et al. 2017). Sobral et al. (2010) reported that ConA and UEA-I lectins have been found useful to differentiate different histological grades of mucoepidermoid carcinoma. ConA lectin was able to stain all grades of mucoepidermoid carcinoma tissues, while UEA-I lectin staining revealed a direct correlation between the intensity of staining and malignancy. Leal et al. (2012) visualized Aspergillus structures in brain and lung tissue samples using HRP-conjugated WGA and ConA. LCA and WFA havebeen used as an FDA authorized glycan deciphering lectins in cancer diagnosis (Gautam et al. 2020).

\subsection{ELLA (enzyme-linked lectin assay)}

The working principle of ELLA is similar to EnzymeLinked Immunosorbent Assay (ELISA) but the difference is in the utilization of capturing as well as detecting reagent. In the case of ELLA, enzyme-conjugated plant lectins are used to detect specific glycans 
on cell surfaces (Hashim et al. 2017). A direct enzymelinked PNA lectin assay was used for pancreatic cancer diagnosis (Ching and Rhodes 1989). Reddi et al. (2000) used enzyme-linked PNA assay to estimate the levels of Thomsen-Friendenreich antigen (T-Ag) in serum of patients with squamous cell carcinoma of the uterine cervix. Bronzoni et al. (2005) detected bronchitis virus and its specific antibodies with ConA-based sandwich ELISA. Leriche et al. (2000) used ConA based ELISA for colorimetric detection of $D$-glucose and D-mannose produced by the biofilms of 10 bacteria strains. Strathmann et al. (2002) also used ConA based ELLSA to characterize extracellular carbohydrates in Pseudomonas aeruginosa biofilms. ELLA technique has high throughput potential and other advantages, as it is easy to perform, very cost-effective, and requires a minimal amount of sample (Mishra et al. 2019).

\section{Potential applications of legume lectins}

\subsection{In plant protection}

Presently, concerns are increasing agriculturists across the globe regarding the attainment of food and nutritional security to millions of people. Emerging evidences have suggested that crop infestation with insects and pathogens is one of the crucial factors jeopardizing global agriculture production and their impacts are likely to be increased in future because of rising food demands and changing climatic conditions (Lehmann et al. 2020). Though chemical based pest management strategies has brought sigificant improvement in crop production, their bad effects on environment and human health have overweighed the benefits associated with their use. Due to changing climatic scenario and sluggish agriculture production, the adoption of environmentally friendly and effective pest management strategies is imperative. The use of plant inhibitory proteins is an effective approach for insect pest management. Lectins have been well documented as potential bio-pesticides (Gatehouse et al. 1995; Powell 2001; Carlini and Grossi-de-Sa 2002) and considered as a potential candidate for generating resistance in susceptible crops. Genes encoding legume lectins have the potential for providing resistance to susceptible crops. Use of lectin genes for transferring insect-pest resistance in plants has an added advantage that the encoding proteins are correctly processed inside the host.

Transgenic wheat plants expressing snowdrop lectin under the influence of constitutive and phloem specific promoters were generated and revealed retarded fecundity of English Grain Aphid (Sitobion avenae) (Stoger et al. 1999). Gatehouse et al. (1999) also reported that feeding of Laconobia oleracea (Tomato moth) on potato plants expressing ConA showed retarded development, decreased larval weight, and decreased fecundity. The pea lectin gene under the control of pollen specific promoter transferred in oilseed rape (Brassica napus) and reduction in the growth of pollen beetles larvae (Melander et al. 2003). Transgenic tobacco plants expressing $\mathrm{MbL}$ protein (Moth bean lectin) showed a significant reduction in the larval weight gain of tobacco cutworm (Singh et al. 2012). Guo et al. (2013) expressed soybean lectin in tobacco plants and revealed resistance against Phytophthora nicotianae and reduced larval weight gain of beet armyworm (Spodoptera exigua). Singh et al. (2016a, b) conferred resistance to Brassica juncea plants against aphid (Lipaphis erysimi) by transferring Vigna radiata lectin gene. Rani et al. (2017) also transformed Brassica juncea plant with Lens culinaris lectin gene using cotyledons explants under the phloem specific promoter.

Numerous lectins are present in vegetables and crops that are routinely consumed by humans and animals. Since many of these plants are eaten raw, these plant lectins are considered non-toxic for humans and mammals in general. However, some legume lectins e.g. ConA and PHA have been known for exerting toxic effects in mammals (Vasconcelos and Oliveira 2004). This signifies the need of conducting toxicity studies concerning the safety issues associated with genetically engineered plants with lectin genes. The use of legume lectins genes for plant transformation could also be considered as a potential way of protection from virus infection (Saha et al. 2006). Fusion proteins containing plant lectins and fusion lectins have strong inhibitory effects on insect development than mixture of individual proteins (Zhu-Salzman et al. 2003; Hossain et al. 2006). Thus, lectin-encoding genes could be used in designing multigene transfer strategies for insect resistance in susceptible crops. Moreover, lectins can also act as a carrier protein to deliver toxic substance to insect haemolymph (Fitches et al. 2002).

\subsection{In glycan analysis}

Glycan research is a fundamental part of cell glycobiology to comprehensively elucidates the functions of glycans either found independently or conjugated to other non-carbohydrate biomolecules (Hirabayashi 
et al. 2001). Lectins have been considered as an important tool to decipher information embedded in the glycode of cells. It has been shown that lectins can be used. Lectins have also been considered as a potential tool to study alteration in glycan profile during various stages of cell growth as well as during pathogenesis. Various lectins-based high throughput molecular tools have been developed to decode complex information stored in glycode. Plant lectin-based affinity chromatography has been used for the identification and purification of glycoproteins. Lectin arrays technique has been developed for high-throughout glycan analysis. Many of the lectins currently used as tools in glycobiology come from plants and the major proportion is constituted by legume lectins. Plant lectins with modified carbohydrate specificity can be useful tool for glycome research (Melnykova et al. 2013). ConA is the most widely used legume lectin for glycan analysis. Other lectins PHA-E and PHA-L, Lens culinaris lectin (LCA), Ulex europaeus agglutinin I, Maackia amurensis leukoagglutinin (MAL) and Griffonia simplicifolia agglutinin have also been used in glycomic research.

\subsection{In plant growth and development}

Typically, legume lectins behave as storage proteins and play vital functions during plant growth and development, which include storage and trafficking of carbohydrates, storage of hormones, and cell-cell interactions via binding with cell surface receptors. Apart from being storage proteins, they have also been reported to play a significant role in plant defense mechanisms. Legume seed lectins have also been reported to be involved in early events of legume-rhizobium symbiosis (De Hoff et al. 2009). Legume seed lectins bind with nod factor (Lipo-oligosaccharide molecules structurally organized as tri, tetra, or pentasaccharides of $\mathrm{N}$-acetylglucosamine) on bacterial surface and assist in initial attachment of symbiotic bacteria to root epidermal cells (Díaz et al. 1989; Van Eijsden et al. 1995). Transgene studies revealed that the introduction of the legume lectins gene could change the nodulation specificity of plants. For example, introduction of soybean lectin gene Lel into Lotus corniculatus, nodulated by Rhizobium loti developed nodules in response to Bradyrhizobium japonicum, which nodulates soybean not Lotus (Van Rhijin et al. 1998). Sreevidya et al. (2005) revealed that the introduction of legume lectin gene can induce colonization of symbiotic bacteria in monocots. In the study, the introduction of pea lectin gene resulted in colonization of root epidermal cell of rice plants (Oryza sativa L. cv. Murasaki) by Rhizobium leguminosarum, Bradyrhizobium japonicum and Rhizobium sp. NGR234). Moreover, transformed plants showed enhanced root growth and lateral root proliferation. The introduction of legume lectin genes can be a potential way of improving the growth of monocot plants (Melnykova et al. 2013). Exogenous application of legume lectins also improves legume-rhizobium symbiosis (Baimiev et al. 2009) that can be relate to the ability of lectins to induce the metabolic changes in bacterial cells and adhesion of microorganisms to root surface. Exogenous application of lectins to seeds can also improve seed germination and plant growth (Kirichenko and Titova 2006). Chimeric lectins/ hybrid lectins, which combine the carbohydrate-binding properties of different lectins, can be introduced into legume plants to expand the range of symbiotic partners under particular soil and climatic conditions. This could lead to a higher nitrogen fixation and correspondingly high yield (Yamamoto et al. 2000; Baimiev et al. 2009; Melnykova et al. 2013).

\subsection{In biomedical research}

The abilility to bind with carbohydrate moieties and glycocojugates has allowed the use of lectins in biomedical research. They have been widely used in identification and profiling of glycans attached to cancer cells and pathogens (Xia and Ng 2006; Blonski et al. 2007; Sobral et al. 2010; Kabir et al. 2013; Silva et al. 2014). Lectins due to their ability to bind with viral glycoproteins inhibit virus entry in host cells, they are considered as alternative antiviral agents against enveloped viruses (Mitchell et al. 2017) and could be used to design devices for viral disease diagnosis via targeting viral glycoproteins or host glycoproteins. Legume lectins induce Th1 respone (de Oliveira et al. 2011b, a; Teixeira et al. 2012) and thus considered as potential vaccine adjuvants (Sander et al. 2019; Nascimento da Silva et al. 2020). Some legume lectins such as SBA, PNA, ConA and PHA interacts glycosylated TLR receptor on macrophage and/or dendritic cells thus can fullfill the role of vaccine adjuvants (Unitt and Hornigold 2011; Sander et al. 2019). The carbohydrate specificity of lectins has also been used to develop various devices for glycan analysis in disease research. The mannose/glucose binding specificity of GNA lectin has been used to modify plasmapheresis apparatus (lectin affinity plasmapheresis, LAP) to 
remove HCV (Hepatitis C virus) (Tullis et al. 2009), Ebola virus (Buttner et al. 2014) and MERS-CoV and Marburg virus (Koch et al. 2018) from blood. Further research is warranted for the future use of lectin affinity plasmapheresis in disease treatment (Nascimento da Silva et al. 2020).

\section{Conclusion and future perspective}

The interactions between carbohydrate moieties and proteins have been recognized crucial for different biological processes such as extracellular and intracellular signaling and cell-to-cell recognition. The carbohydrate binding specificity of lectins makes them a valuable tool in the study of glycoconjugates and for understanding the mechanisms of many biological processes. Within the group of plant lectins, legume lectins are an extensively investigated homologous proteins with variability in their carbohydrate specificity and diverse biological functions. Legume lectins are important tools in glycobiogy and are considered as the best model system to investigate protein-carbohydrate interactions. Role of legume lectins as plant defense protein and their utilization as potential antimicrobial agents for drug development and drug therapies has also been well documented. Considering the crucial role of legume lectins in plant defense, the lectin genes could be used for designing strategies for multigene transfer to generate resistance in susceptible crops. Lectins from legumes have been implicated in the development of different lectin-based high throughput molecular tools and have established as an important glycan deciphering tool in glycobiology. However, still there is a lot of scope for harnessing the potential of lectins for different biotechnological and biomedical applications. Moreover, the identification and characterization of novel legume lectins and in depth investigation on existing legume lectins will have profound effect on the further development of field of lectinology.

\section{References}

Adar R, Moreno JE, Karlsson KA, Streicher H and Sharon N 1998 Structural studies of the combining site of Erythrina collarodendron lectin. Protein Sci. 7 52-63

Adar R and Sharon N 1996 Mutational studies of the combining site residues of Erythrina corallodendron lectin. Eur. J. Biochem. 239 668-674
Ahmed SF, Quadeer AA and McKay MR 2020 Preliminary identification of potential vaccine targets for the COVID19 coronavirus (SARS-CoV-2) based on SARS-CoV immunological studies. Viruses 12 1-12

Akkouh O, Ng TB, Singh SS, Yin C, Dan X, et al. 2015 Lectins with anti-HIV activity: A review. Molecules 20 648-668

Amin ARMR, Paul RK, Thakur VS and Agarwal ML 2007 A novel role for $\mathrm{p} 73$ in the regulation of Akt-Foxo1a-Bim signaling and apoptosis induced by the plant lectin, Concanavalin A. Cancer Res. 67 5617-5621

Andrade CAS, Oliveira MD, de Melo CP, Coelho LCBB, Correia MTS, et al. 2011 Diagnosis of dengue infection using a modified gold electrode with hybrid organicinorganic nanocomposite and Bauhinia monandra lectin. J. Colloid Interface Sci. 362 517-523

Ang ASW, Cheung RCF, Dan X, Chan YS, Pan W, et al. 2014 Purification and characterization of a glucosaminebinding antifungal lectin from Phaseolus vulgaris cv. Chinese Pinto Beans with antiproliferative activity towards nasopharyngeal carcinoma cells. Appl. Biochem. Biotechnol. 172 672-686

Aoki K, Perlman M, Lim JM, Cantu R, Wells L, et al. 2007 Dynamic developmental elaboration of N-linked glycan complexity in Drosophila melanogaster embryo. J. Biol. Chem. 282 9127-9142

Arora R, Sharma HC, Van Dreissche E and Sharma KK 2005 Biological activity of lectins from grain legumes and garlic against the legume pod borer, Helicoverpa armigera. Int. Chick Pea Pigeon Pea News Lett. 12 50-52

Avelino K, Andrade C, DeMelo C, NogueiraM CorreiaM, et al. 2014 Biosensor based on hybrid nanocomposite and CramoLL lectin for detection of dengue glycoproteins in real samples. Synth. Met. 194 102-108

Ayouba A, Causse H, Vandamme EJM, Peumans WJ, Bourne Y, et al. 1994 Interactions of plant-lectins with the components of the bacterial-cell wall peptidoglycan. Biochem. Syst. Ecol. 22 153-159

Babosha AV 2008 Inducible lectins and plant resistance to pathogens and abiotic stress. Biochemistry (mosc) 73 812-825

Bămiev AKh, Gubắdullin II, Bămiev AKh and Cheremis AV 2009 Effects of natural and hybrid lectins on the legume-rhizobium interactions]. Prikl. Biokhim. Mikrobiol. 45 84-91

Banerjee R, Das K, Ravishankar R, Suguna K, Surolia A, et al. 1996 Conformation, protein-carbohydrate interactions and a novel subunit association in the refined structure of peanut lectin-lactose complex. J. Mol. Biol. 259 281-296

Bantel H, Engels I, Voelter W, Schulze-Osthoff K and Wesselborg S 1999 Mistletoe lectin activates caspase-8/ FLICE independently of death receptor signaling and enhances anticancer drug-induced apoptosis. Cancer Res. 59 2083-2090 
Barbieri L, Balteli MG and Stirpe F 1993 Ribosome inactivating proteins from plants. Biochim. Biophys. Acta 1154 237-284

Barton C, Kouokam JC, Lasnik AB, Foreman O, Cambon A, et al. 2014 Activity of and effect of subcutaneous treatment with the broad-spectrum antiviral lectin griffithsin in two laboratory rodent models. Antimicrob Agents Chemother 58 120-127

Bellande K, Bono JJ, Savelli B, Jamet E and Canut H 2017 Plant lectins and lectin receptor-like kinases: How do they sense the outside? Int. J. Mol. Sci. 181164

Beltrão EIC, Correia MTS, Figueredo-Silva J and Coelho LCBB 1998 Binding evaluation of isoform 1 from Cratylia mollis lectin to human mammary tissues. Appl. Biochem. Biotech. 74 125-134

Beltrão E, Medeiros P, Rodrigues O, Figueredo-Silva J, Valença M, et al. 2003 Parkia pendula lectin as histochemistry marker for meningothelial tumor. Eur. J. Histochem. 47 139-142

Benevides R, Ganne G, Simões R, Schubert V, Niemietz M, et al. 2012 A lectin from Platypodium elegans with unusual specificity and affinity for asymmetric complex N-glycans. J. Biol. Chem. 287 26352-26364

Bezerra EH, Rocha BA, Nagano CS, Bezerra Gde A, Moura TR, et al. 2011 Structural analysis of ConBr reveals molecular correlation between the carbohydrate recognition domain and endothelial NO synthase activation. Biochem. Biophys. Res. Commun. 408 566-570

Bhutia SK, Panda PK, Sinha N, Praharaj PP, Bhol CS, et al. 2019 Plant lectins in cancer therapeutics: Targeting apoptosis and autophagy-dependent cell death. Pharmacol. Res. 144 8-18

Blonski K, Milde-Langosch K, Bamberger AM, Osterholz T, Utler C, et al. 2007 Ulex europeus agglutinin-I binding as a potential prognostic marker in ovarian cancer. Anticancer Res. 27 2785-2790

Boleti APA, Freire MG, Coelho MB, Silva W, Baldasso PA, et al. 2007 Insecticidal and antifungal activity of a protein from Pouteria torta seeds with lectin-like properties. $J$. Agric. Food Chem. 55 2653-2658

Botos I and Wlodawer A 2003 Cyanovirin-N: a sugarbinding antiviral protein with a new twist. Cell Mol. Life Sci. 60 277-287

Boulter D, Edwards GA, Gatehouse AMR, Gatehouse JA and Hilder VA 1990 Additive protective effects of incorporating two different higher plant derived insect resistance genes in transgenic tobacco plants. Crop Prot. 9 351-354

Bourne Y, Rouge P and Cambillau C 1990 3-Dimensional structures of complexes of Lathyrus ochrus Isolectin I with glucose and mannose: Fine Specificity of the monosaccharide-binding site. Proteins 8 365-376

Bourne Y, Ayouba A, Rouge P and Cambillau C 1994 Interaction of a legume lectin with two components of the bacterial cell wall. A Crystallographic Study. J. Biol. Chem. 269 9429-9435

Boyd WC and Reguera RM 1949 Hemagglutinating substances for human cells in various plants. J. Immunol. 62 333-339

Boyd WC and Shapleigh E 1954 Antigenic relations of blood group antigens as suggested by tests with lectins. $J$. Immunol. 73 226-231

Broekaert WF, Van Parijs J, Leyns F, Joos H and Peumans WJ 1989 A chitin-binding lectin from stinging nettle rhizomes with antifungal properties. Science $\mathbf{2 4 5}$ 1100-1102

Bronzoni R, Montassier M, Montassier S, Pereira G, Gama $\mathrm{N}$, et al. 2005 Detection of infectious bronchitis virus and specific anti-viral antibodies using a Concanavalin A-Sandwich-ELISA. Viral Immunol. 18 569-578

Brooks SA and Carter TM 2001 N-acetylgalactosamine, $\mathrm{N}$-acetylglucosamine and sialic acid expression in primary breast cancer. Acta Histochem. 103 37-51

Buts L, Dao-Thi MH, Loris R, Wyns L, Etzler M, et al. 2001 Weak protein-protein interactions in lectins: the crystal structure of a vegetative lectin from the legume Dolichos biflorus. J. Mol. Biol. 309 193-201

Buttner S, Koch B, Dolnik O, Eickmann M, Freiwald T, et al. 2014 Extracorporeal virus elimination for the treatment of severe Ebola virus disease: First experience with lectin affinity plasmapheresis. Blood Purif. 38 286-291

Cai Q and Zhang ZR 2005 Lectin-mediated cytotoxicity and specificity of 5-fluorouracil conjugated with peanut agglutinin (5-Fu-PNA) in vitro. J. Drug Target 13 251-257

Cao J, Guo S, Arai K, Lo EH and Ning M 2013 Studying extracellular signaling utilizing a glycoproteomic approach: lectin blot surveys, a first and important step. Methods Mol. Biol. 1013 227-233

Capell T, Twyman, R, Armario N, Victoria, Ma J, et al. 2020 Potential applications of plant biotechnology against SARS-CoV-2. Trends Plant Sci. 25 https://doi.org/10. 1016/j.tplants.2020.04.009

Carlini CR and Grossi-de-Sa MF 2002 Plant toxic proteins with insecticidal properties: a review on their potentialities as bio-insecticides. Toxicon 40 1515-1539

Carrington DM, Auffret A and Hanke DE 1985 Polypeptide ligation occurs during post-translational modification of Concanavalin A. Nature 313 64-67

Cavada BS, Osterne VJS, Lossio CF, Pinto-Junior VR, Oliveira MV, et al. 2019 One century of ConA and 40 years of ConBr research: A structural review. Int. J. Biol. Macromol. 134 901-911

Cavada BS, Osterne VJS, Oliveira MV, Pinto-Junior VR, Silva MTL, et al. 2020 Reviewing Mimosoideae lectins: A group of under explored legume lectins. Int. J. Biol. Macromol. 154 159-165 
Chan YS, Wong JH, Fang EF, Pan W and Ng TB 2012 Isolation of a glucosamine binding leguminous lectin with mitogenic activity towards splenocytes and antiproliferative activity towards tumor cells. PLOS ONE 7 e38961

Chan YS, Wong JH, Fang EF, Pan W and Ng TB 2013 A hemagglutinin from northeast red beans with immunomodulatory activity and anti-proliferative and apoptosis-inducing activities toward tumor cells. Protein Pept. Lett. 20 1159-1169

Chan YS, Xia L and Ng TB 2016 White kidney bean lectin exerts anti-proliferative and apoptotic effects on cancer cells. Int. J. Biol. Macromol. 85 335-345

Chandra NR, Kumar N, Jeyakani J, Singh DD, Gowda SB, et al. 2006 Lectindb: a plant lectin database. Glycobiology Adv. 16 938-946

Chang CP, Yang MC, Liu HS, Lin YS and Lei HY 2007 Concanavalin A induces autophagy in hepatoma cells and has a therapeutic effect in a murine in situ hepatoma model. Hepatology 45 286-296

Chen J, Liu B, Ji N, Zhou J, Bian HJ, et al. 2009 A novel sialic acid-specific lectin from Phaseolus coccineus seeds with potent antineoplastic and antifungal activities. Phytomedicine 16 352-360

Ching CK and Rhodes JM 1989 Enzyme-linked PNA lectin binding assay compared with CA19-9 and CEA radioimmunoassay as a diagnostic blood test for pancreatic cancer. Br. J. Cancer 59 949-953

Chrispeels MJ and Raikhel NV 1991 Lectins, lectin genes and their role in plant defense. Plant Cell 3 1-9

Coelho LCBB, Silva PM, Lima VL, Pontual EV, Paiva PM, et al. 2017 Lectins, interconnecting proteins with biotechnological/pharmacological and therapeutic applications. Evid. Based Complement Alternat. Med. 1594074 https:// doi.org/10.1155/2017/1594074.

Collinge D, Kragh KM, Mikkelsen JD, Nielsen KK, Rasmussen U, et al. 1993 Plant chitinases. Plant J. 3 $31-40$

Crimeen-Irwin B, Scalzo K, Gloster S, Mottram PL and Plebanski M 2005 Failure of immune homeostasis: The consequences of under and over reactivity. Endocr. Metab. Immune Disord. Drug Targets 5 413-423

Cummings RD, Etzler ME and Surolia A 2017 L-Type Lectins; in Essentials of Glycobiology (eds) A Varki, RD Cummings, JD Esko, HH Freeze, P, Stanley, CR Bertozzi, GW Hart and ME Etzler (New York: Cold Spring Harbor Laboratory Press)

Czapla TH and Lang BA 1990 Effect of plant lectins on the larval development of European corn borer (Lepidoptera: Pyralidae) and southern corn rootworm (Coleoptera: Chrysomelidae). J. Econ. Entonlol. 83 2480-2485

Dang K, Zhang W, Jiang S, Lin X and Qian A 2020 Application of lectin microarrays for biomarker discovery. ChemistryOpen 9 285-300
De Hoff PL, Brill LM and Hirsch AM 2009 Plant lectins: The ties that bind in root symbiosis and plant defense. Mol. Genet. Genom. 282 1-15

de Melo CML, Melo H, Correia MTS, Coelho LCBB, da Silva MB, et al. 2011 Mitogenic response and cytokine production induced by Cramoll 1,4 lectin in splenocytes of inoculated mice. Scand. J. Immunol. 73 112-121

de Melo CML, Paim BA, Zecchin KG, Morari J, Chiaratti MR, et al. 2010 Cramoll 1, 4 lectin increases ROS production, calcium levels, and cytokine expression in treated spleen cells of rats. Mol. Cellular Biochem. 342 163-169

de Oliveira Silva F, das Neves Santos P, DeMelo CM, Teixeira E, Benildo C, et al. 2011a Immunostimulatory activity of ConBr: a focus on splenocyte proliferation and proliferative cytokine secretion. Cell Tissue Res. 346 237-244

de Oliveira Figueirôa E, Aranda-Souza MÂ, Varejão N, Rossato FA, Costa RAP, et al. 2017 pCramoll and rCramoll lectins induce cell death in human prostate adenocarcinoma (PC-3) cells by impairment of mitochondrial homeostasis. Toxicol. Vitro 43 40-46

De Schutter K and Van Damme EJM 2015 Proteincarbohydrate interactions as part of plant defense and animal immunity. Molecules 20 9029-9053

de Souza GA, Oliveira PS, Trapani S, Santos AC, Rosa JC, et al. 2003 Amino acid sequence and tertiary structure of Cratylia mollis seed lectin. Glycobiology 13 961-972

de Sousa LM, de Carvalho JL, da Silva HC, Lemos TLG, Arriaga AMC, et al. 2016 New cytotoxic bibenzyl and other constituents from Bauhinia ungulate L. (Fabaceae). Chem. Biodiversity 13 1630-1635

Delatorre P, Rocha BA, Souza EP, Oliveira TM, Bezerra GA, et al. 2007 Structure of a lectin from Canavalia gladiata seeds: new structural insights for old molecules. $B M C$ Struct. Biol. 7 1-9

Delbaere LT, Vandonselaar M, Prasad L, Quail JW, Wilson K, et al. 1993 Structures of the lectin IV of Griffonia simplicifolia and its complex with the Lewis b human blood group determinant at $2.0 \AA$ resolution. J. Mol. Biol. 230 950-965

Dell A and Morris HR 2001 Glycoprotein structure determination by mass spectrometry. Science 291 2351-2356

Derewenda Z, Yariv J, Helliwell JR, Kalb AJ, Dodson EJ, et al. 1989 The structure of the saccharide-binding site of Concanavalin-A. EMBO J. 8 2189-2193

Dessen A, Sacchettini JC, Gupta D, Brewer CF and Sabesan S 1995 X-ray crystal structure of the soybean agglutinin cross-linked with a biantennary analog of the blood group I carbohydrate antigen. Biochemistry 34 4933-4942

Díaz CL, Melchers LS, Hooykaas PJJ, Lugtenberg EJJ and Kijne JW 1989 Root lectin as a determinant of hostplant specificity in the Rhizobium-legume symbiosis. Nature 338 579-581 
D'Onofrio M, Lee MD, Starr CM, Miller M and Hanover JA 1991 The gene encoding rat nuclear pore glycoprotein p62 is intronless. J. Biol. Chem. 266 11980-11985

Durham M and Regnier FE 2006 Targeted glycoproteomics: serial lectin affinity chromatography in the selection of O-glycosylation sites on proteins from the human blood proteome. J. Chromatogr. a. 1132 165-173

Drickamer K 1997 Making a fitting choice: common aspects of sugar-binding sites in plant and animal lectins. Structure 5 465-468

Edelman GM, Cunningham BA, Reeke GN Jr, Becker JW, Waxdal MJ, et al. 1972 The covalent and three-dimensional structure of Concanavalin A. Proc. Natl. Acad. Sci. 69 2580-2584

El-Araby MM, El-Shatoury EH, Soliman MM, et al. 2020 Characterization and antimicrobial activity of lectins purified from three Egyptian leguminous seeds. $A M B$ Expr.

Elgavish S and Shaanan B 1998 Structures of the Erythrina carallodendron lectin and of its complexes with monoand disaccharides. J. Mol. Biol. 277 917-932

Faheina-Martins GV, Silveira ALD, Cavalcanti BC, Ramos MV, Moraes MO, et al. 2012 Antiproliferative effects of lectins from Canavalia ensiformis and Canavalia brasiliensis in human leukemia cell lines. Toxicol. in Vitro 26 1161-1169

Fang EF, Pan WL, Wong JH, Chan YS, Ye XJ, et al. 2011 A new Phaseolus vulgaris lectin induces selective toxicity on human liver carcinoma Hep G2 cells. Arch. Toxicol. 85 $1551-1563$

Fang EF, Pan WL, Wong JH, Tsao SW and NgTB, 2010 A lectin with anti-HIV-1 reverse transcriptase, antitumor, and nitric oxide inducing activities from seeds of Phaseolus vulgaris cv. Extralong Autumn Purple Bean. J. Agric. Food Chem. 58 2221-2229

Felton GW 2005 Indigestion is a plant's best defense. Proc. Nat. Acad. Sci. USA 102 18771-18772

Filho RMM, Rossiter JG, Cavalcanti Junior EA and Martins LSS 2017 In Silico comparative analysis of legume lectins. J. Genet. Genomes 1 1-11

Fitches E and Gatehouse JA 1998 A comparison of the short and long term effects of insecticidal lectins on the activities of soluble and brush border enzymes of tomato moth larvae (Laconobia oleracea). J. Insect Physiol. 44 1213-1224

Fitches E, Ilett C, Gatehouse AMR, Gatehouse LN, Greene R, Edwards JP, et al. 2001a The effects of Phaseolus vulgaris erythro and leucoagglutinating isolectins (PHA-E and PHA-L) delivered via artificial diet and transgenic plants on the growth and development of tomato moth (Lacanobia oleracea) larvae; lectin binding to gut glycoproteins in vitro and in vivo. J. Insect Physiol. 47 1389-1398

Fitches E, Woodhouse SD, Edwards JP and Gatehouse JA $2001 \mathrm{~b}$ In vitro and in vivo binding of snowdrop
(Galanthus nivalis agglutinin; GNA) and jackbean (Canavalia ensiformis; ConA) lectins within tomato moth (Lacanobia oleracea) larvae; mechanisms of insecticidal action. J. Insect Physiol. 47 777-787

Fitches E, Audsley N, Gatehouse JA and Edwards JP 2002 Fusion proteins containing neuropeptides as novel insect control agents: snowdrop lectin delivers fused allatostatin to insect haemolymph following oral ingestion. Insect Biochem. Mol. Biol. 32 1653-1661

Fung TS and Liu DX 2018 Post-translational modifications of coronavirus proteins: Roles and function. Futur. Virol. $13405-430$

Galasso I, Lioi L, Lanave C, Bollini R and Sparvoli F 2004 Identification and isolation of lectin nucleotide sequences and species relationships in the genus Lens (Miller). Theor. Appl. Genet. 108 1098-1102

Gatehouse AMR, Davison GM, Stewart JN, Gatehouse LN, Kumar A, et al. 1999 Concanavalin A inhibits development of tomato moth (Lacanobia oleracea) and peachpotato aphid (Myzus persicae) when expressed in transgenic potato plants. Mol. Breed. 5 153-165

Gatehouse AMR, Dewey FM, Dove J, Fenton KA and Pusztai A 1984 Effect of seed lectins from Phaseolus vulgaris on the development of larvae of Callosobruchus maculates, mechanism of toxicity. J. Sci. Food Agric. 35 373-380

Gatehouse AMR, Powell KS, Peumans WJ, Van Damme EJM and Gatehouse JA 1995 Insecticidal properties of plant lectins: their potential in plant protection; in Lectins: biomedical perspectives (eds) A Pusztai and S Bardocz (London: Taylor and Francis) pp 35-58

Gautam A, Sharma D, Sharma J and Saini K 2020 Legume lectins: Potential use as a diagnostics and therapeutics against the Cancer. Int. J. Biol. Macromol. 142 474-483

Gautam AK, Srivastava N, Sharma B and Bhagyawant S 2018a Current scenario of legume lectins and their practical applications. J. Crop Sci. Biotechnol. 21 217-227

Gautam AK, Gupta N, Narvekar DT, Bhadkariya R and Bhagyawant SS 2018b Characterization of chick pea (Cicer arietinum L.) lectin for biological activity. Physiol. Mol. Biol. Plants 24 389-397

Gavrovic-Jankulovic M and Prodanovic R 2011 Drug Delivery: Plant lectins as bioadhesive drug delivery systems. J. Biomater. Nanobiotechnol. 2 614-621

Geethanandan K, Abhilash J, Bharath SR, Sadasivan C and Haridas M 2011 X-ray structure of a galactose-specific lectin from Spatholobous parviflorous. Int. J. Biol. Macromol. 49 992-998

Gegg CV, Roberts DD, Segal IH and Etzler ME 1992 Characterization of the adenine binding sites of two Dolichos biflorus lectins. Biochemistry 31 6938-6942

Goldstein IJ and Hayes CE 1978 The lectins: Carbohydratebinding proteins of plants and animals. Adv. Carbohyd. Chem. Biochem. 35 127-340 
Goldstein IJ and Poretz RD 1986 Isolation, physicochemical characterization and carbohydrate-binding specificity of lectins. In: The Lectins: Properties, functions and applications in biology and medicine (eds) IE Liener, N Sharon and IJ Goldsteinet (Florida: Academic Press) pp 35-247

Gondim ACS, Romero-Canelón I, Sousa EHS, Blindauer CA, Butler JS, et al. 2017 The potent anti-cancer activity of Dioclea lasiocarpa lectin. J. Inorg. Biochem. 175 179-189

Grandhi NJ, Mamidi AS and Surolia A 2015 Pattern recognition in legume lectins to extrapolate amino acid variability to sugar specificity. Adv. Exp. Med. Biol. 842 199-215

Guo P, Wang Y, Zhou X, Xie Y, Wu H and Gao X 2013 Expression of soybean lectin in transgenic tobacco results in enhanced resistance to pathogens and pests. Plant Sci. 211 17-22

Habibi J, Backus E and Huesing J 2000 Effects of phytohemagglutinin (PHA) on the structure of midgut epithelial cells and localization of its binding sites in western tarnished plant bug, Lygus hesperus Knight. $J$. Insect Physiol. 46 611-619

Haji-Ghassemi O, Gilbert M, Spence J, Schur MJ, Parker MJ, et al. 2016 Molecular basis for recognition of the cancer glycobiomarker, LacdiNAc (GalNAc $[\beta 1 \rightarrow 4]$ GlcNAc), by Wisteria floribunda Agglutinin. J. Biol. Chem. 291 24085-24095

Hamelryck TW, Loris R, Bouckaert J, Dao-Thi MH, Strecker G, et al. 1999 Carbohydrate binding, quaternary structure and a novel hydrophobic binding site in two legume lectin oligomers from Dolichos biflorus. J. Mol. Biol. 286 1161-1177

Hamelryck TW, Moore JG, Chrispeels MJ, Loris R and Wyns L 2000 The role of weak protein-protein interactions in multivalent lectin-carbohydrate binding: Crystal structure of cross-linked FRIL. J. Mol. Biol. 299 875-883

Hansen JE, Nielsen CM, Nielsen C, Heegaard P, Mathiesen LR and Nielsen JO 1989 Correlation between carbohydrate structures on the envelope glycoprotein gp120 of HIV-1 and HIV-2 and syncytium inhibition with lectins. AIDS 3 635-641

Hardman KD and Ainsworth CF 1972 Structure of concanavalin $\mathrm{A}$ at 2.4-A resolution. Biochemistry $\mathbf{1 1}$ 4910-4919

Hashim OH, Jayapalan JJ and Lee CS 2017 Lectins: an effective tool for screening of potential cancer biomarkers. Peer J. 5 e 3784

Hegedus DD, Erlandson M, Gillott C and Toprak U 2009 New insights into peritrophic matrix synthesis, architecture and function. Ann. Rev. Entomol. 54 285-302

Hirabayashi J and ArataY and Kasai K, 2001 Glycome project: concept, strategy and preliminary application to Caenorhabditis elegans. Proteomics 1 295-303

Hong S, Kwon J, Kim D and Yang S 2015 A rapid, sensitive and selective electrochemical biosensor with
Concanavalin A for the preemptive detection of norovirus. Biosens. Bioelectron. 64 338-344

Hossain MA, Maiti MK, Basu A, Sen S, Ghosh AK, et al. 2006 Transgenic expression of onion leaf lectin gene in indian mustard offers protection against aphid colonization. Crop Sci. 46 2022-2032

Hostanska K, Vuong V, Rocha S, Soengas MS, Glanzmann C, et al. 2003 Recombinant mistletoe lectin induces p53independent apoptosis in tumour cells and cooperates with ionising radiation. Br. J. Cancer $\mathbf{8 8} 1785-1792$

Hua W, Han L and Wang Z 2015 Molecular cloning and expression of a novel gene related to legume lectin from Salvia miltiorrhiza Bunge. Afr. J. Biotechnol. 14 2234-2243

Huang LH, Yan QJ, Kopparapu NK, Jiang ZQ and Sun Y 2012 Astragalus membranaceus lectin (AML) induces caspase-dependent apoptosis in human leukemia cells. Cell Prolif. 45 15-21

Ikemoto K, Shimizu K, Ohashi K, Takeuchi Y, Shimizu M, et al. 2016 Bauhinia purprea agglutinin-modified liposomes for human prostate cancer treatment. Cancer Sci. $10753-59$

Imberty A, Gautier C, Lescar J, Pérez S, Wyns L, et al. 2000 An unusual carbohydrate binding site revealed by the structures of two Maackia amurensis lectins complexed with sialic acidcontaining oligosaccharides. J. Biol. Chem. 275 17541-17548

Ingale A and Hivrale A 2013 Plant as a plenteous reserve of lectin. Plant Sig. behave. 8 https://doi.org/10.4161/psb. 26595

Islam B and Khan AU 2012 Lectins: To combat infections; in Protein Purification (ed) Ahmad R, (Rijeka: InTech) pp. $167-188$

Issa E, Merhi G, Panossian B, Salloum T and Tokajian S 2020 SARS-CoV-2 and ORF3a: Nonsynonymous mutations, functional domains, and viral pathogenesis. $\mathrm{mSys}$ tems 5 https://doi.org/10.1128/mSystems.00266-20

Jain SK and Jangdey MS 2009 Lectin conjugated gastroretentive multiparticulate delivery system of clarithromycin for the effective treatment of Helicobacter pylori. Mol. Pharm. 6 295-304

Janzen DH, Juster HB and Liener IE 1976 Insecticidal action of the phytohaemagglutenin in black bean on a bruchid beetle. Science 192 795-796

Jordinson M, El-Hariry I, Calnan D, Calam J and Pignatelli M 1999 Vicia faba agglutinin, the lectin present in broad beans, stimulates differentiation of undifferentiated colon cancer cells. Gut 44 709-714

Kabir SR, Nabi MM, Haque A, Zaman RU, Mahmud ZH, et al. 2013 Pea lectin inhibits growth of Ehrlich ascites carcinoma cells by inducing apoptosis and $\mathrm{G}_{2} / \mathrm{M}$ cell cycle arrest in vivo in mice. Phytomedicine 20 1288-1296

Katoch R 2020 Insect pest resistance factors in rice bean; in Ricebean: Exploiting the nutritional potential of an 
underutilized legume (Singapore: Springer Nature) pp 233-270

Katoch R, Singh SK, Thakur N, Dutt S, Yadav SK, et al. 2014 Cloning, characterization, expression analysis and inhibition studies of a novel gene encoding bowman-birk type protease inhibitor from rice bean. Gene 546 342-351

Katoch R and Tripathi A 2017 Nutraceutical and pharmacological Properties of Vigna species. Indian J. Agric. Biochem. 30 10-20

Katoch R, Tripathi A and Neelam and Thakur N, 2016 Current perspective of plant protection strategies using inhibitory proteins. Indian J. Agric. Biochem. 29 124-133

Katrlík J, Svitel J, Gemeiner P, Kozár T and Tkac J 2010 Glycan and lectin microarrays for glycomics and medicinal applications. Med. Res. Rev. 30 394-418

Keyaerts E, Vijgen L, Pannecouque C, Van Damme E, Peumans W, et al. 2007 Plant lectins are potent inhibitors of corona viruses by interfering with two targets in the viral replication cycle. Antiviral Res. 75 179-187

Kezuka Y, Kojima M, Mizuno R, Suzuki K, Watanabe T, et al. 2010 Structure of full-length class I chitinase from rice revealed by X-ray crystallography and small-angle X-ray scattering. Proteins 78 2295-2305

Kilpatrick DC 1999 Mechanisms and assessment of lectinmediated mitogenesis. Mol. Biotechnol.

Kirichenko EV and Titova LV 2006 Soybean lectin as a component of a composite biopreparation involving Bradyrhizobium japonicum 634b. Prikl. Biokhim. Mikrobiol. 42 219-223

Kirichenko EV, Titova LV, Zhemoida AV and Omel'chuk S 2004 Influence of legume plants lectins with different specificity on the development of crop seedlings. Fisiol. Biokhim. Kult. Rast. 36 390-397

Kluková L, Filip J, Belicky S, Vikartovská A and Tkac J 2016 Graphene oxide-based electrochemical label-free detection of glycoproteins down to aM level using a lectin biosensor. The Analyst. 141 https://doi.org/10.1039/ C6AN00793G

Koch B, Schult-Dietrich P, Buttner S, Dilmaghani B, Lohmann D, et al. 2018 Lectin affinity plasmapheresis for Middle East respiratory syndrome-coronavirus and Marburg virus glycoprotein elimination. Blood Purif. 46 126-133

Konno A, Hoshino Y, Terashima S, Motoki R and Kawaguchi T 2002 Carbohydrate expression profile of colorectal cancer cells is relevant to metastatic pattern and prognosis. Clin. Exp. Metastasis 19 61-70

Kovalchuk NV, Melnykova NM and Musatenko LI 2012 Role of phytolectins in the life cycle of plants. Biopolym. Cell 28 171-180

Krokhin O, Li Y, Andonov A, Feldmann H, Flick R, et al. 2003 Mass spectrometric characterization of proteins from the SARS virus: a preliminary report. Mol. Cell Proteomics 2 346-356
Kumar S, Kapoor V, Gill K, Singh K, Xess I, et al. 2014 Antifungal and antiproliferative protein from Cicer arietinum: A bioactive compound against emerging pathogens. BioMed Res. Inter Article ID 387203 https://doi. org $/ 10.1155 / 2014 / 387203$

Kundhavai Natchiar S, Arockia Jeyaprakash A, Ramya TN, Thomas CJ, Suguna K, et al. 2004 Structural plasticity of peanut lectin: an X-ray analysis involving variation in $\mathrm{pH}$, ligand binding and crystal structure. Acta Crystallogr. D Biol. Crystallogr. 60 211-219

Lagarda-Diaz I, Guzman-Partida AM and Vazquez-Moreno L 2017 Legume lectins: Proteins with diverse applications. Int. J. Mol. Sci. $\mathbf{1 8}$ https://doi.org/10.3390/ ijms 18061242

Lagarda-Diaz I, Guzman-Partida AM, Urbano-Hernandez G, Ortega-Nieblas MM, Robles-Burgueño MR, et al. 2009 Insecticidal action of PF2 lectin from Olneya tesota (Palo Fierro) against Zabrotes subfasciatus larvae and midgut glycoconjugate binding. J. Agric. Food Chem. 57 689-694

Lai YC, Chuang YC, Chang CP and Yeh TM 2015 Macrophage migration inhibitory factor has a permissive role in concanavalin A-induced cell death of human hepatoma cells through autophagy. Cell Death Dis. 6 e2008

Laija SN, Mahesh S, Smitha LS and Remani P 2010 Isolation and partial characterization of two plant lectins. Curr. Res. J. Biol. Sci. 2 232-237

Lam SK and Ng TB 2010 First report of a haemagglutinininduced apoptotic pathway in breast cancer cells. Biosci. Rep. 30 307-317

Lambin J, Asci SD, Dubiel M. Tsaneva M, Verbeke I, et al. 2020 OsEUL lectin gene expression in rice: stress regulation, subcellular localization and tissue specificity. Front. Plant Sci. 11 https://doi.org/10.3389/fpls.2020. 00185

Lannoo N and Van Damme EJM 2010 Nucleocytoplasmic plant lectins. Biochim. Biophys. Acta 1800 190-201

Lannoo N and Van Damme EJM 2014 Lectin domains at the frontiers of plant defense. Front. Plant Sci.

Leal FG, Lopes NEP, Clark ATR, De Pontes Filho NT, Beltrao EIC, et al. 2012 Carbohydrate profiling of fungal cell wall surface glycoconjugates of Aspergillus species in brain and lung tissues using lectin histochemistry. Med. Mycol. J. 50 756-759

Lehmann P, Ammunét T, Barton M, Battisti A, Eigenbrode $\mathrm{SD}$, et al. 2020 Complex responses of global insect pests to climate warming. Front. Ecol. Environ. 18 141-150

Leriche V, Sibille P and Carpentier B 2000 Use of an enzyme-linked lectinsorbent assay to monitor the shift in polysaccharide composition in bacterial biofilms. Appl. Environ. Microbiol. 66 1851-1856

Li F, Feng Y, Yang L, Li L, Tang C and Tang B 2011 A selective novel non-enzyme glucose amperometric 
biosensor based on lectin-sugar binding on thionine modified electrode. Biosens. Bioelectron. 26 2489-2494

Lioi L, Galasso I, Santantonio M, Lanave C, Bollini R, et al. 2006 Lectin gene sequences and species relationships among cultivated legumes. Genet. Resour. Crop Evol. 53 1615-1623

Lis H and Sharon N 1998 Lectins: Carbohydrate-specific proteins that mediate cellular recognition. Chem. Rev. 98 $637-674$

Liu B, Cheng Y, Zhang B, Bian HJ and Bao JK 2009 Polygonatum cyrtonema lectin induces apoptosis and autophagy in human melanoma A375 cells through a mitochondria-mediated ROS-p38-p53 pathway. Cancer Lett. 275 54-60

Liu YM, Shahed-Al-Mahmud M, Chen X, Chen TH, Liao $\mathrm{KS}$, et al. 2020 A carbohydrate-binding protein from the edible Lablab beans effectively blocks the infections of influenza viruses and SARS-CoV-2. Cell Rep. 32 https:// doi.org/10.1016/j.celrep.2020.108016

Liu Z, Liu B, Zhang ZT, Zhou TT, Bian HJ, et al. 2008 A mannose-binding lectin from Sophora flavescens induces apoptosis in HeLa cells. Phytomedicine 15 867-875

Loris R, De Greve H, Dao-Thi MH, Messens J, Imberty A, et al. 2000 Structural basis of carbohydrate recognition by lectin II from Ulex europaeus, a protein with a promiscuous carbohydrate-binding site. J. Mol. Biol. 301 987-1002

Loris R, Hamelryck T, Bouckaert J and Wyns L 1998 Legume lectin structure. Biochim. Biophys. Acta 1383 9-36

Loris R, Imberty A, Beeckmans S, Van Driessche E, Read JS, et al. 2003 Crystal structure of Pterocarpus angolensis lectin in complex with glucose, sucrose and turanose. $J$. Biol. Chem. 278 16297-16303

Loris R, Van Overberge D, Dao-Thi MH, Poortmans F, Maene N, et al. 1994 Structural analysis of two crystal forms of lentil lectin at $1.8 \AA$ resolution. Proteins 20 330-346

Luan J, Lu Y, Jin X and Zhang L 2020 Spike protein recognition of mammalian ACE2 predicts the host range and an optimized ACE2 for SARS-CoV-2 infection. Biochem. Biophys. Res. Commun. 526 165-169

Lubkowski J, Durbin SV, Silva MC, Farnsworth D, Gildersleeve JC, et al. 2017 Structural analysis and unique molecular recognition properties of a Bauhinia forficata lectin that inhibits cancer cell growth. FEBS J. $\mathbf{2 8 4}$ $429-450$

Luna D, Oliveira M, Nogueira M and Andrade C 2014 Biosensor based on lectin and lipid membranes for detection of serum glycoproteins in infected patients with dengue. Chem. Phys. Lipids 180 https://doi.org/10.1016/j. chemphyslip.2014.02.008

Lyu SY, Choi SH and Park WB 2002 Korean mistletoe lectin-induced apoptosis in hepatocarcinoma cells is associated with inhibition of telomerasevia mitochondrial controlled pathway independent of p53. Arch. Pharm. Res.

Ma F, Rehman A, Sims M and Zeng X 2015 Antimicrobial susceptibility assays based on the quantification of bacterial lipopolysaccharides via a label free lectin biosensor. Anal. Chem. 87 4385-4393

Macedo ML, Freire MDGM, Da Silvam MB and Coelho LC 2007 Insecticidal action of Bauhinia monandra leaf lectin (BmoLL) against Anagasta kuehniella (Lepidoptera: Pyralidae), Zabrotes subfasciatus and Callosobruchus maculates (Coleoptera: Bruchidae). Comp. Biochem. Physiol. Mol. Integr. Physiol. 146 486-498

Macedo MLR, Oliveira CFR and Oliveira TC 2015 Insecticidal activity of plant lectins and potential application in crop protection. Molecules 20 2014-2033

Majumder P, Mondal HA and Das S 2005 Insecticidal activity of Arum maculatum tuber lectin and its binding to the glycosylated insect gut receptors. J. Agric. Food Chem. 53 6725-6729

Maliarik MJ and Goldstein IJ 1988 Photoaffinity labeling of the adenine binding site of the lectins from Lima bean, Phaseolus lunatus, and the kidney bean, Phaseolus vulgaris. J. Biol. Chem. 263 11274-11279

Manoj N and Suguna K 2001 Signature of quaternary structure in the sequences of legume lectins. Protein Eng. Des. Sel. 14 735-745

Marafioti T, Barresi G and Batolo D 1994 Lectin histochemistry of human meningiomas. Histol. Histopathol. 3 535-540

Melander M, Ahman I, Kamnert I and Stromdahl AC 2003 Pea lectin expressed transgenically in oilseed rape reduces growth rate of pollen beetle larvae. Transgenic Res. 12 555-567

Melnykova N, Mykhalkiv L, Mamenko P and Kots S 2013 The areas of application for plant lectins. Biopolym. Cell 29 357-366

Michiels K, Van Damme EJM and Smagghe G 2010 Plantinsect interactions: What can we learn from plant lectins? Arch. Insect Biochem. Physiol. 73 193-212

Min W, Dunn AJ and Jones DH 1992 Non-glycosylated recombinant pro-Concanavalin $\mathrm{A}$ is active without polypeptide cleavage. EMBO J. 11 1303-1307

Mishra A, Behura A, Mawatwal S, Kumar A, Naik L, et al. 2019 Structure-function and application of plant lectins in disease biology and immunity. Food Chem Toxicol. 110827 https://doi.org/10.1016/j.fct.2019.110827

Mitchell CA, Ramessar K and O'Keefe BR 2017 Antiviral lectins: Selective inhibitors of viral entry. Antiviral Res. 142 37-54

Miyoshi E, Moriwaki K, Terao N, Tan CC, Terao M, et al. 2012 Fucosylation is a promising target for cancer diagnosis and therapy. Biomolecules 2 34-45

Monzo A, Bonn GK and Guttman A 2007 Lectin-immobilization strategies for affinity purification and separation of glycoconjugates. Trends Analyt. Chem. 26 423-432 
Moreira RA, Ainouz IL, Oliveira JTA and Cavada BS 1991 Plant lectins, chemical and biological aspects. Mem. Inst. Oswaldo Cruz. 86 211-218

Moreno FB, Bezerra GA, Oliveira TM, de Souza EP, da Rocha BA, et al. 2007 Structural analysis of Canavalia maritima and Canavalia gladiata lectins complexed with different dimannosides: new insights into the understanding of the structure-biological activity relationship in legume lectins. J. Struct. Biol. 160 168-176

Mukhopadhyay S, Panda P, Das D, Sinha N, Behera B, et al. 2014 Abrus agglutinin suppresses human hepatocellular carcinoma in vitro and in vivo by inducing caspasemediated cell death. Acta Pharmacol. Sin. 35 814-824

Müller WE, Renneisen K, Kreuter MH, Schröder HC and Winkler I 1988 The D-mannose-specific lectin from Gerardia savaglia blocks binding of human immunodeficiency virus type I to H9 cells and human lymphocytes in vitro. J. Acquir. Immune Defic. Syndr. 1 453-458

Murdock LL, Huesing JE, Nielsen SS, Pratt RC and Shade RE 1990 Biological effects of plant lectins on the cowpea weevil. Phytochemistry 29 85-89

Nagae M, Soga K, Morita-Matsumoto K, Hanashima S, Ikeda A, Yamamoto K, et al. 2014 Phytohemagglutinin from Phaseolus vulgaris (PHA-E) displays a novel glycan recognition mode using a common legume lectin fold. Glycobiology 24 368-378

Naik S and Kumar S 2020 Biochemical Characterization of lactose binding Entadin lectin from Entada rheedii seeds with cytotoxic activity against cancer cell lines. $A C S$ Omega 5 16430-16439

Nascimento da Silva LC, Mendonça JSP, Oliveira WF, Batista KLR, Zagmignan A, et al. 2020 Exploring lectinglycan interactions to combat COVID-19: Lessons acquired from other enveloped viruses. Glycobiology cwaa099 https://doi.org/10.1093/glycob/cwaa099

Nishimura A, Sawada S, Ushiyama I, Yamamoto Y, Tokiko $\mathrm{N}$, et al. 2000 Lectin-histochemical detection of degenerative glycoconjugate deposits in human brain. Forensic Sci. Int. 113 265-269

Nóbrega RB, Rocha BA, Gadelha CA, Santi-Gadelha T, Pires AF, et al. 2012 Structure of Dioclea virgata lectin Relations between carbohydrate binding site and nitric oxide production. Biochimie 94 900-906

Nonomura A, Shevela D, Komath S, Biel K and Govindjee G 2020 The carbon reactions of photosynthesis: role of lectins and glycoregulation. Photosynthetica $\mathbf{5 8}$ 1090-1097

Norton P, Comunale MA, Herrera H, Wang M, Houser J, et al. 2016 Development and application of a novel recombinant Aleuria aurantia lectin with enhanced core fucose binding for identification of glycoprotein biomarkers of hepatocellular carcinoma. Proteomics $\mathbf{1 6}$ 3126-3136

Oliveira MD, Nogueira ML, Correia MTS, Coelho LCBB and Andrade CAS 2011b Detection of dengue virus serotypes on the surface of gold electrode based on Cratylia mollis lectin affinity. Sens. Actuat. B Chem. 155 789-795

Olsen LR, Dessen A, Gupta D, Sabesan S, Sacchettini JC, et al. 1997 X-ray crystallographic studies of unique crosslinked lattices between four isomeric biantennary oligosaccharides and soybean agglutinin. Biochemistry 36 15073-15080

Ou X, Liu Y, Lei X, Li P, Mi D, et al. 2020 Characterization of spike glycoprotein of SARS-CoV-2 on virus entry and its immune cross-reactivity with SARS-CoV. Nat. Commun.

Panda PK, Mukhopadhyay S, Behera B, Bhol CS, Dey S, et al. 2014 Antitumor effect of soybean lectin mediated through reactive oxygen species-dependent pathway. Life Sci. 111 27-35

Pandey G, Fatma T, Cowsik SM and Komath SS 2009 Specific interaction of jacalin with phycocyanin, a fluorescent phycobiliprotein. J. Photochem. Photobiol. B. $9787-93$

Patil DN, Datta M, Dev A, Dhindwal S, Singh N, et al. 2013 Structural investigation of a novel N-Acetyl-Glucosamine binding chi-lectin which reveals evolutionary relationship with class III chitinases. PLoS ONE 8 e63779

Peumans WJ and Van Damme EJM 1995 Lectins as plant defense proteins. Plant Physiol. 109 347-352

Peumans WJ, Van Damme JM, Barre A and Rouge P 2001 Classification of plant lectins in families of structurally and evolutionary related proteins. Adv. Exp. Med. Biol. $49127-54$

Pinto LS, Nagano CS, Oliveira TM, Moura TR, Sampaio AH, et al. 2008 Purification and molecular cloning of a new galactose-specific lectin from Bauhinia variegata seeds. J. Biosci. 33 355-363

Polito L, Bortolotti M, Farini V, Battelli MG, Barbieri L, et al. 2009 Saporin induces multiple death pathways in lymphoma cells with different intensity and timing as compared to ricin. Int. J. Biochem. Cell Biol. 41 1055-1061

Powell KS 2001 Antimetabolic effects of plant lectins towards nymphal stages of the plant hoppers Tarophagous proserpina Nilaparvata lugens. Entomol. Exp. Appl. 99 71-77

Powell KS, Spence J, Brarathi M, Gatehouse CJA and Gatehouse AMR 1998a Immunohistochemical and developmental studies to elucidate the mechanism of action of the snowdrop lectin on the rice brown planthopper, Nilaparvata lugens (Stal). J. Insect Physiol. 44 529-539

Prasthofer T, Phillips SR, Suddath FL and Engler JA 1989 Design, expression, and crystallization of recombinant lectin from the garden pea (Pisum sativum). J. Biol. Chem. 264 6793-6796

Procópio TF, Moura MC, Albuquerque LP, Gomes FS, Santos NDL, et al. 2017 Antibacterial lectins: action mechanisms, defensive roles and biotechnological 
potential; in Antibacterials: Synthesis, Properties and Biological Activities (ed) Collins E (New York: Nova Science Publishers) pp 69-89

Procópio TF, de Siqueira Patriota LL, de Moura MC, da Silva PM, de Oliveira APS, et al. 2017b CasuL: A new lectin isolated from Calliandra surinamensis leaf pinnulae with cytotoxicity to cancer cells, antimicrobial activity and antibiofilm effect. Int. J. Biol. Macromol. 98 419-429

Qadir S, Wani IH, Rafiq S, Ganie SA, Masood A and Hamid R 2013 Evaluation of antimicrobial activity of a lectin isolated and purified from Indigofera Heterantha. Adv. Biosci. Biotechnol. 4 https://doi.org/10.4236/abb.2013. 411133

Rabijns A, Verboven C, Rouge P, Barre A, Van Damme EJM, et al. 2001 Structure of a legume lectin from the bark of Robinia pseudoacacia and its complex with $\mathrm{N}$-acetylgalactosamine. Proteins 44 470-478

Rafiq S, Majeed R, Qazi AK, Ganai BA, Wani I, et al. 2013 Isolation and antiproliferative activity of Lotus corniculatus lectin towards human tumour cell lines. Phytomedicine 21 30-38

Rahbé Y and Febvay G 1993 Protein toxicity to aphids: an in vitro test on Acyrthosiphon pisum. Entomol. Exp. Appl. 67 149-160

Rahbe Y, Sauvion N, Febvay G, Peumans WJ and Gatehouse AMR 1995 Toxicity of lectins and processing of ingested proteins in the pea aphid Acyrthosiphon pisum. Entomol. Exp. Appl. 76 143-155

Ramnath V, Rekha PS, Kuttan G and Kuttan R 2007 Regulation of caspase-3 and bcl-2 expression in Dalton's Lymphoma Ascites cells by abrin. Evid. Based Complement Alternat. Med. Ecam 6 233-238

Rani S, Sharma V, Hada A and Koundal KR 2017 Efficient genetic transformation of Brassica juncea with lectin using cotyledons explants. Int. J. Adv. Biotechnol. Res. 7 $1-12$

Rao KV, Rathore KS, Hodges TK, Fu X, Stoger E, et al. 1998 Expression of snowdrop lectin (GNA) in transgenic rice plants confers resistence to rice brown plant hopper. The Plant J. 15 469-477

Reddi AL, Sankaranarayanan K, Arulraj HS, Devaraj N and Devaraj H 2000 Enzyme-linked PNA lectin-binding assay of serum T-antigen in patients with SCC of the uterine cervix. Cancer Lett. 149 207-211

Reeke GN Jr and Becker JW 1986 Three-dimensional structure of favin: saccharide binding-cyclic permutation in leguminous lectins. Science 234 1108-1111

Reyes-Lopez CA, Hernandez-Santoyo A, Pedraza-Escalona M, Mendoza G, Hernandez-Arana A and RodriguezRomero A 2004 Insights into a conformational epitope of Hev b 6.02 (hevein). Biochem. Biophys. Res. Commun. 314 123-130

Rini JM 1995 Lectin structure. Ann. Rev. Biophys. Biomol. Struc. 24 551-577
Roberts DD and Goldstein IJ 1983 Adenine binding sites of the lectin from lima beans (Phaseolus lunatus). J. Biol. Chem. 258 13820-13824

Roy B, Pattanaik AK, Das J, Bhutia SK, Behera B, et al. 2014 Role of PI3K/Akt/mTOR and MEK/ERK pathway in Concanavalin A induced autophagy in HeLa cells. Chem. Biol. Interact. 210 96-102

Sadeghi A, Smagghe G, Broeders S, Hernalsteens JP, De Greve H, et al. 2008 Ectopically expressed leaf and bulb lectin from garlic (Allium sativum L.) protect transgenic tobacco plants against cotton leafworm (Spodoptera littoralis). Transgenic Res. 17 9-8

Saha P, Majumder P, Dutta I, Ray T, Roy SC, et al. 2006 Transgenic rice expressing Allium sativum leaf lectin with enhanced resistance against sap-sucking insect pests. Planta 223 1329-1343

Sahid S, Roy C, Paul S and Datta R 2020 Rice lectin protein Osr40c1 imparts drought tolerance by modulating OsSAM2, OsSAP8 and chromatin-associated proteins. bioRxiv 2020 https://doi.org/10.1101/2020.04.19.049288

Sammour RH and El-Shanshoury A 1992 Antimicrobial activity of legume seed proteins. Bot. Bull. Acad. Sin. 31 185-190

Sander VA, Corigliano MG and Clemente M 2019 Promising plant-derived adjuvants in the development of coccidial vaccines. Front. Vet. Sci.

Sanders DA, Moothoo DN, Raftery J, Howard AJ, Helliwell JR, et al. 2001 The $1.2 \AA$ resolution structure of the ConA-dimannose complex. J. Mol. Biol. 310 875-884

Satomaa T, Heiskanen A, Leonardsson I, Angstrom J, Olonen A, et al. 2009 Analysisof the human cancer glycome identifies a novel group of tumor-associated N-acetylglucosamine glycan antigens. Cancer Res. 69 5811-5819

Sauvion N, Nardon C, Febvay G, Angharad M, Gatehouse $\mathrm{R}$, et al. 2004a Binding of the insecticidal lectin Concanavalin A in pea aphid, Acyrthosiphon pisum (Harris) and induced effects on the structure of midgut epithelial cells. J. Insect Physiol. 50 1137-1150

Sauvion N, Rahbe Y, Peumans WJ, Van Damme EJM, Gatehouse JA, et al. 1996 Effects of GNA and other mannose binding lectins on development and fecundity of the potato-peach aphid Myzus persicae. Entomol. Exp. Appl. 79 285-293

Sauvion N, Charles H, Febvay G and Rahbé Y 2004b Effects of jackbean lectin (ConA) on the feeding behaviour and kinetics of intoxication of the pea aphid, Acyrthosiphon pisum. Entomol. Exp. Appl. 110 31-44

Schlumbaum A, Mauch F, Vogeli U and Boller T 1986 Plant chitinases are potent inhibitors of fungal growth. Nature 324 365-367

Schnell DJ and Etzler ME 1988 cDNA cloning, primary structure and in vitro biosynthesis of the DB58 lectin from Dolichos biflorus. J. Biol. Chem. 263 14648-14653 
Shaanan B and Elgavish S 1998 Structures of the Erythrina corallodendron lectin and of its complexes with mono and disaccharides. J. Mol. Biol. 277 917-932

Shan S, Tanaka H and Shoyama Y 2001 Enzyme-linked immunosorbent assay for glycyrrhizin using anti-glycyrrhizin monoclonal antibody and an eastern blotting technique for glucuronides of glycyrrhetic acid. Anal. Chem. 73 5784-5790

Sharma V and Surolia A 1997 Analyses of carbohydrate recognition by legume lectins: Size of the combining site loops and their primary specificity. J. Mol. Biol. 267 433-445

Sharon N and Lis H 2001 The structural basis for carbohydrate recognition by lectins. Adv. Exp. Med. Biol. $4911-16$

Sharon N and Lis H 2004 History of lectins: from hemagglutinins to biological recognition molecules. Glycobiology 14 53R-62R

Sharon N and Lis H 2002 How proteins bind carbohydrates: Lessons from legume lectins. J. Agric. Food Chem. 50 6586-6591

Shetty KN, Latha VL, Rameshwaram NR, Nadimpalli SK and Suguna K 2013 Affinity of a galactose-specific legume lectin from Dolichos lablab to adenine revealed by X-ray cystallography. IUBMB Life 65 633-644

Shi Z, Chen J, Li CY, An N, Wang ZJ, et al. 2014 Antitumor effects of Concanavalin A and Sophora flavescens lectin in vitro and in vivo. Acta Pharmacol. Sin. 35 248-256

Shukla S, Arora R and Sharma HC 2005 Biological activity of soybean trypsin inhibitor and plant lectins against cotton bollworm/legume pod borer, Helicoverpa armigera. Plant Biotechnol. 22 1-6

Silva HC, da Silva Pinto L, Teixeira E, do Nascimento KS, Cavada B, et al. 2013 BUL: A novel lectin from Bauhinia ungulata $\mathrm{L}$. seeds with fungistatic and antiproliferative activities. Process Biochem. 49 203-209

Silva MC, de Paula CA, Ferreira JG, Paredes-Gamero EJ, Vaz AM, et al. 2014 Bauhinia forficata lectin (BfL) induces cell death and inhibits integrin-mediated adhesion on MCF7 human breast cancer cells. Biochim. Biophys. Acta 1840 2262-2271

Simao EP, Silva DBS, Cordeiro MT, Gil LHV, Andrade CAS, et al. 2020 Nanostructured impedimetric lectinbased biosensor for arboviruses detection. Talanta

Singh P, Tiwari P, Sabat BC and Kansal R 2016a Cloning and in vitro expression of insecticidal Vigna radiata lectin gene in $E$. coli and its efficacy against major sap-sucking pests in transgenic Brassica Juncea. Int. J. Agric. Sci. Res. 6 123-133

Singh P, Tiwari P, Sabat BC, Prajapat RK and Kansal R $2016 \mathrm{~b}$ Use of Vigna radiata lectin gene in development of transgenic Brassica Juncea resistant to aphids. Int. J. Agric. Sci. Res. 6 199-210

Singh R, Tiwari M, Jagdeesh HM, Kansal R, Gupta RN, et al. 2012 Isolation of lectin gene and development of resistant Nicotiana tabacum L. against Spodoptera litura. Indian J. Biotechnol. 11 143-141

Sitohy M, Doheim M and Badr H 2007 Isolation and characterization of a lectin with antifungal activity from Egyptian Pisum sativum seeds. Food Chem. 104 971-979

Sobral AP, Rego MJ, Cavalacanti CL, Carvalho LB Jr and Beltrao EI 2010 ConA and UEA-I lectin histochemistry of parotid gland mucoepidermoid carcinoma. J. Oral Sci. 52 49-54

Sohrab S, Suhail M, Kamal M, Ahmad F and Azhar E 2020 Emergence of human pathogenic Coronaviruses: Lectins as antivirals for SARS-CoV-2. Curr. Pharm. Des. 26 https://doi.org/10.2174/1381612826666200821120409

Sousa BL, Silva Filho JC, Kumar P, Pereira RI, Lyskowski A, et al. 2015 High-resolution structure of a new Tn antigen-binding lectin from Vatairea macrocarpa and a comparative analysis of Tn-binding legume lectins. Int. J. Biochem. Cell Biol. 59C 103-110

Sprawka I, Goławska S, Parzych T, Goławski A, Chrzanowski G, et al. 2014 Entomotoxic action of jackbean lectin (ConA) in bird cherry-oat aphid through the effect on insect enzymes. J. Plant. Inte. 9 425-433

Sprawka I, Goławska S, Parzych T, Goławski A, Sytykiewicz $\mathrm{H}$, et al. 2013 Induction of apoptosis in the grain aphid Sitobion avenae (Hemiptera: Aphididae) under the influence of phytohaemagglutinin PHA. Appl. Entomol. Zool. 48 525-532

Sprawka I, Goławska S, Parzych T, Sytykiewicz H and Czerniewicz P 2015 Apoptosis induction by concanavalin A in gut cells of grain aphid. Arthropod-Plant Inte. 9 $133-140$

Sreevidya VS, Hernandez-Oane RJ, So RB, Sullia SB, Stacey G, et al. 2005 Expression of the legume symbiotic lectin genes psl and gs52 promotes rhizobial colonization of roots in rice. Plant Sci. 169 726-736

Srinivas VR, Acharya S, Rawat S, Sharma V and Surolia A 2000 The primary structure of the acidic lectin from winged bean (Psophocarpus tetragonolobus): Insights in carbohydrate recognition, adenine binding and quaternary association. FEBS Lett. 474 76-82

Srinivasan N, Rufino SD, Pepys MB, Wood S and Blundell TL 1996 A superfamily of proteins with the lectin fold. Chemtracts. Biochem. Mol. Biol. 6 149-164

Srivastava S, Banu S, Singh P, Sowpati TD and Mishra RK 2021 SARS-CoV-2 genomics: An Indian perspective on sequencing viral variants. J. Biosci.

Sternberg A and Naujokat C 2020 Structural features of coronavirus SARS-CoV-2 spike protein: Targets for vaccination. Life Sci. 257 https://doi.org/10.1016/j.lfs. 2020.118056

Stillmark H 1888 Über Ricin ein giftiges Ferment aus den Samen von Ricinus communis L. und einige anderen Euphorbiaceen. MD Thesis, University of Dorpat, Dorpat, Estonia 
Stirk HJ, Woolfson DN, Hutchinson EG and Thornton JM 1992 Depicting topology and handedness in jellyroll structures. FEBS Lett. 308 1-3

Stoger E, Williams S, Christou P, Down RE and Gatehouse JA 1999 Expression of the insecticidal lectin from snowdrop (Galanthus nivalis agglutinin; GNA) in transgenic wheat plants: effects on predation by the grain aphid Sitobion avenae. Mol. Breed. 5 65-73

Strathmann M, Wingender J and Flemming HC 2002 Application of fluorescently labelled lectins for the visualization and biochemical characterization of polysaccharides in biofilms of Pseudomonas aeruginosa. $J$. Microbiol. Methods 50 237-248

Sumi S, Arai K, Kitahara S and Yoshida K 1999 Serial lectin affinity chromatography demonstrates altered asparaginelinked sugar-chain structures of prostate-specific antigen in human prostate carcinoma. J. Chromatogr. B Biomed. Sci. Appl. 727 9-14

Sumner JB and Howell SF 1936 The identification of the hemagglutinin of the jack bean with Concanavalin A. $J$. Bacteriol. 32 227-237

Svensson C, Teneberg S, Nilsson CL, Kjellberg A, Schwarz FP, et al. 2002 High resolution crystal structures of Erythrina cristagalli lectin in complex with lactose and $2^{\prime}-\alpha$-L-fucosyllactose and correlation with thermodynamic binding data. J. Mol. Biol. 321 69-83

Swamy MJ, Sastry MVK and Surolia A 1985 Prediction and comparison of the secondary structure of legume lectins. J. Biosci. $9203-212$

Tang XT, Ibanez F and Tamborindeguy C 2020 Concanavalin A toxicity towards Potato Psyllid and apoptosis induction in midgut cells. Insects $\mathbf{1 1}$ https://doi.org/10. 3390/insects 11040243

Teixeira E, Francisco A, Nascimento KS, Victor C, Celso N, et al. 2012 Biological applications of plants and algae lectins: An overview; in Carbohydrates: Comprehensive studies on glycobiology and glycotechnology (ed) ChuanFa Chang (Lodon: Intech Open) pp 533-558

Tempel W, Tschampel S and Woods RJ 2002 The xenograft antigen bound to Griffonia simplicifolia lectin 1-B(4). $\mathrm{X}$-ray crystal structure of the complex and molecular dynamics characterization of the binding site. J. Biol. Chem. 277 6615-6621

Tsaneva M and Van Damme EJM 2020130 years of plant lectin research. Glycoconj. J. 37 533-551

Tullis RH, Duffin RP, Handley HH, Sodhi P, Menon J, et al. 2009 Reduction of hepatitis C virus using lectin affinity plasmapheresis in dialysis patients. Blood Purif. 27 64-69

Unitt J and Hornigold D 2011 Plant lectins are novel Tolllike receptor agonists. Biochem. Pharmacol. 81 1324-1328

Vainauskas S, Duke RM, McFarland J, McClung C, Ruse C, et al. 2016 Profiling of core fucosylated $\mathrm{N}$-glycans using a novel bacterial lectin that specifically recognizes $\alpha-1,6$ fucosylated chitobiose. Sci. Rep. 6 https://doi.org/10. 1038/srep34195

Van Damme EJ, Barre A, Rougé P, Van Leuven F and Peumans WJ 1995 The seed lectins of black locust (Robinia pseudoacacia) are encoded by two genes which differ from the bark lectin genes. Plant Mol. Biol. 29 $1197-1210$

Van Damme EJM 2014 History of plant lectin research. Methods Mol. Biol. 1200 3-13

Van Damme EJM, Balzarini J, Smeets K, Van Leuven F and Peumans WJ 1994 The monomeric and dimeric mannose binding proteins from the Orchidaceae species Listeru ovata and Epipactis helleborine: sequence homologies and differences in biolclgical activities. Glycoconj. J. 11 321-332

Van Damme EJM, Barre A, Rougé P and Peumans WJ 2004 Cytoplasmic/nuclear plant lectins: A new story. Trends Plant Sci. 9 484-489

Van Damme EJM, Fouquaert E, Lannoo N, Vandenborre G, Schouppe D, et al. 2011 Novel concepts about the role of lectins in the plant cell; in The Molecular Immunology of Complex Carbohydrates-3 (ed) AM Wu (New York: Springer) pp 295-324

Van Damme EJM, Nausicaa L and Peumans WJ 2008 Plant Lectins; in Advances in botanical research (eds) JC Kader and M Delseny (San Diego: Elsevier Ltd.) pp 107-209

Van Damme EJM, Peumans WJ, Barre A and Rouge P 1998 Plant Lectins: A composite of several distinct families of structurally and evolutionary related proteins with diverse biological roles. Cric. Rev. Plant Sci. 17 575-692

Van Eijsden RR, de Pater BS and Kijne JW 1994 Mutational analysis of the sugar-binding site of pea lectin. Glycoconj. J. 11 375-380

Van Holle S, De Schutter K, Eggermont L, Tsaneva M, Dang J, et al. 2017 Comparative study of lectin domains in model species: new insights into evolutionary dynamics. Int. J. Mol. Sci.

Van Holle S and Van Damme EJM 2018 Signaling through plant lectins: modulation of plant immunity and beyond. Biochem. Soc. Trans. 46 217-233

Van Rhijin P, Goldberg RB and Hirsch AM 1998 Lotus corniculatus nodulation specificity is changed by the presence of a soybean lectin gene. Plant Cell $\mathbf{1 0}$ $1233-1250$

Van Rhijn P, Fujishige NA, Lim PO and Hirsch AM 2001 Sugar-binding activity of pea (Pisum sativum) lectin is essential for heterologous infection of transgenic alfalfa (Medicago sativa L.) plants by Rhizobium leguminosarum biovar viciae. Plant Physiol 125 133-144

Vandenborre G, Smagghe G and Van Damme EJM 2011 Plant lectins as defense proteins against phytophagous insects. Phytochemistry 72 1538-1550

Vankadari N and Wilce JA 2020 Emerging WuHan (COVID-19) coronavirus: Glycan shield and structure 
prediction of spike glycoprotein and its interaction with human CD26. Emerg. Microbes Infect. 9 601-604

Vasconcelos IM and Oliveira JTA 2004 Antinutritional properties of plant lectins. Toxicon 44 385-403

Verma J, Subbarao N and Rajala MS 2020 Envelope proteins as antiviral drug target. J. Drug Target 28 1046-1052

Vitale A, Ceriotti A, Bollini R and Chrispeels MJ 1984 Biosynthesis and processing of phytohemagglutinin in developing bean cotyledons. Eur. J. Bioche. 141 97-104

Wales R, Richardson PT, Roberts LM, Woodland HR and Lord JM 1991 Mutational analysis of the galactose binding ability of recombinant ricin B chain. J. Biol. Chem. 266 19172-19179

Walls AC, Park YJ, Tortorici MA, Wall A, McGuire AT, et al. 2020 Structure, function, and antigenicity of the SARS-CoV-2 spike glycoprotein. Cell 181 281-292

Wang P, Leng X, Duan J, Zhu Y, Wang J, Yan Z, Min S, Wei $\mathrm{D}$, et al. 2021 Functional component isolated from Phaseolus vulgaris lectin exerts in vitro and in vivo anti-tumor activity through potentiation of apoptosis and immunomodulation. Molecules

Wang W, Hause B, Peumans WJ, Smagghe G, Mackie A, et al. 2003 The Tn antigen-specific lectin from ground ivy is an insecticidal protein with an unusual physiology. Plant Physiol. 132 1322-1334

War AR, Paulraj MG, Hussain B, Buhroo AA, Ignacimuthu S, et al. 2013 Effect of plant secondary metabolites on legume pod borer, Helicoverpa armigera. J. Pest Sci. 86 399-408

Wu J, Wang J, Wang S and Rao P 2016 Lunatin, a novel lectin with antifungal and antiproliferative bioactivities from Phaseolus lunatus billb. Int. J. Biol. Macromol. 89 717-724

Xia L and Ng TB 2006 A hemagglutinin with mitogenic activity from dark red kidney beans. J. Chromatogr. B Analyt. Technol. 844 213-216

Yaghoubi M, Rahimi F, Negahdari B, Rezayan AH and Shafiekhani A 2020 A lectin-coupled porous siliconbased biosensor: label-free optical detection of bacteria in a real-time mode. Sci. Rep.

Corresponding editor: BJ RAO
Yamamoto K, Konami Y and Osawa T 2000 A chimeric lectin formed from Bauhinia purpurea lectin and Lens culinaris lectin recognizes a unique carbohydrate structure. J. Biochem. 127 129-135

Yamauchi D and Minamikawa T 1990 Structure of the gene encoding Concanavalin A from Canavalia gladiata and its expression in Escherichia coli cells. FEBS Lett. 260 127-130

Yan Q, Li Y, Jiang Z, Sun Y, Zhu L and Ding Z 2009 Antiproliferation and apoptosis of human tumor cell lines by a lectin (AMML) of Astragalus mongholicus. Phytomedicine 16 586-593

Yan QJ, Jiang ZQ, Yang SQ, Deng W and Han LJ 2005 A novel homodimeric lectin from Astragalus Mongholicus with antifungal activity. Arch. Biochem. Biophys. 442 $72-81$

Ye XJ and Ng TB 2011 Antitumor and HIV-1 reverse transcriptase inhibitory activities of a hemagglutinin and a protease inhibitor from mini-black soybean. Evid. Based Complement Alternat. Med. Article ID 851396 https://doi. org/10.1155/2011/851396

Ye XY, Ng TB, Tsang PWK and Wang J 2001 Isolation of a homodimeric lectin with antifungal and antiviral activities from red kidney bean (Phaseolus vulgaris) seeds. $J$. Protein Chem. 20 367-375

Zhu-Salzman K and Salzman RA 2001 Functional mechanics of the plant defensive Griffonia simplicifolia lectin II: resistance to proteolysis is independent of glycoconjugate binding in the insect gut. J. Econ. Entomol. 94 1280-1284 Zhu-Salzman K, Ahn JE, Salzman RA, Koiwa H, Shade RE, et al. 2003 Fusion of a soybean cysteine protease inhibitor and a legume lectin enhances antiinsect activity synergistically. Agric. Forest Enthomol. 5 317-323

Zhu-Salzman K, Shade RE, Koiwa H, Salzman RA, Narasimhan M, et al. 1998 Carbohydrate binding and resistance to proteolysis control insecticidal activity of Griffonia simplicifolia lectin II. Proc. Nat. Acad. Sci. USA $9515123-15128$ 